\title{
Neurotoxic Effects of Neonicotinoids on Mammals: What Is There beyond the Activation of Nicotinic Acetylcholine Receptors?-A Systematic Review
}

\author{
Carmen Costas-Ferreira (D) and Lilian R. F. Faro * (D) \\ Departamento de Biología Funcional y Ciencias de la Salud, Facultad de Biología, Universidade de Vigo, \\ 36310 Vigo, Spain; maica.cf@hotmail.com \\ * Correspondence: lilianfaro@uvigo.es; Tel.: +34-986-130212; Fax: +34-986-812556
}

check for updates

Citation: Costas-Ferreira, C.; Faro, L.R.F. Neurotoxic Effects of

Neonicotinoids on Mammals: What Is

There beyond the Activation of

Nicotinic Acetylcholine Receptors?

-A Systematic Review. Int. J. Mol. Sci. 2021, 22, 8413. https://doi.org/ $10.3390 /$ ijms 22168413

Academic Editor: Steeve

Hervé Thany

Received: 13 July 2021

Accepted: 2 August 2021

Published: 5 August 2021

Publisher's Note: MDPI stays neutral with regard to jurisdictional claims in published maps and institutional affiliations.

Copyright: (c) 2021 by the authors. Licensee MDPI, Basel, Switzerland. This article is an open access article distributed under the terms and conditions of the Creative Commons Attribution (CC BY) license (https:/ / creativecommons.org/licenses/by/ $4.0 /)$.
Abstract: Neonicotinoids are a class of insecticides that exert their effect through a specific action on neuronal nicotinic acetylcholine receptors (nAChRs). The success of these insecticides is due to this mechanism of action, since they act as potent agonists of insect nAChRs, presenting low affinity for vertebrate nAChRs, which reduces potential toxic risk and increases safety for non-target species. However, although neonicotinoids are considered safe, their presence in the environment could increase the risk of exposure and toxicity. On the other hand, although neonicotinoids have low affinity for mammalian nAChRs, the large quantity, variety, and ubiquity of these receptors, combined with its diversity of functions, raises the question of what effects these insecticides can produce in non-target species. In the present systematic review, we investigate the available evidence on the biochemical and behavioral effects of neonicotinoids on the mammalian nervous system. In general, exposure to neonicotinoids at an early age alters the correct neuronal development, with decreases in neurogenesis and alterations in migration, and induces neuroinflammation. In adulthood, neonicotinoids induce neurobehavioral toxicity, these effects being associated with their modulating action on nAChRs, with consequent neurochemical alterations. These alterations include decreased expression of $\mathrm{nAChRs,} \mathrm{modifications} \mathrm{in} \mathrm{acetylcholinesterase} \mathrm{activity,} \mathrm{and} \mathrm{significant} \mathrm{changes} \mathrm{in} \mathrm{the}$ function of the nigrostriatal dopaminergic system. All these effects can lead to the activation of a series of intracellular signaling pathways that generate oxidative stress, neuroinflammation and, finally, neuronal death. Neonicotinoid-induced changes in $\mathrm{AChR}$ function could be responsible for most of the effects observed in the different studies.

Keywords: neonicotinoids; mechanism of action; cholinergic system; mammals; neurotoxicity; central nervous system

\section{Introduction}

Neonicotinoids (NNs) are an emerging class of synthetic pesticides that represent the largest market share worldwide [1]. There are at least seven commercial varieties of NNs, imidacloprid (IMI), thiamethoxam (TMX), clothianidin (CLO), thiacloprid (THI), acetamiprid (ACE), dinotefuran (DIN) and nitenpyran (NIT) $[2,3]$. This group of insecticides is increasingly used as substitutes for organophosphates and methylcarbamates, whose efficacy has declined considerably in recent years due to organism resistance and greater restrictions on their use due to toxicological considerations [4,5]. Currently, NNs are marketed in more than 120 countries and are among the most effective insecticides worldwide in the control of sucking insects and certain chewing species, in both agriculture and pets $[1,2,6]$.

NNs were designed to be structurally similar to nicotine and, like this substance, they also act on the cholinergic neurotransmitter system [7]. Figure 1 presents the chemical structures of the main NNs in comparison with nicotine. Specifically, NN pesticides exert their neurotoxicity in target insects by acting as potent agonists of nicotinic acetylcholine 
receptors (nAChRs), which are widely distributed in the central nervous system (CNS) of these invertebrates $[5,8]$. The nAChRs are ligand gated ion channel that, when activated, allow small cations to pass through for several milliseconds before closing back to a resting or desensitized state [9]. NNs bind tightly to the alpha subunits of nAChRs and block them, causing neuromuscular paralysis and ultimately death $[3,10,11]$.

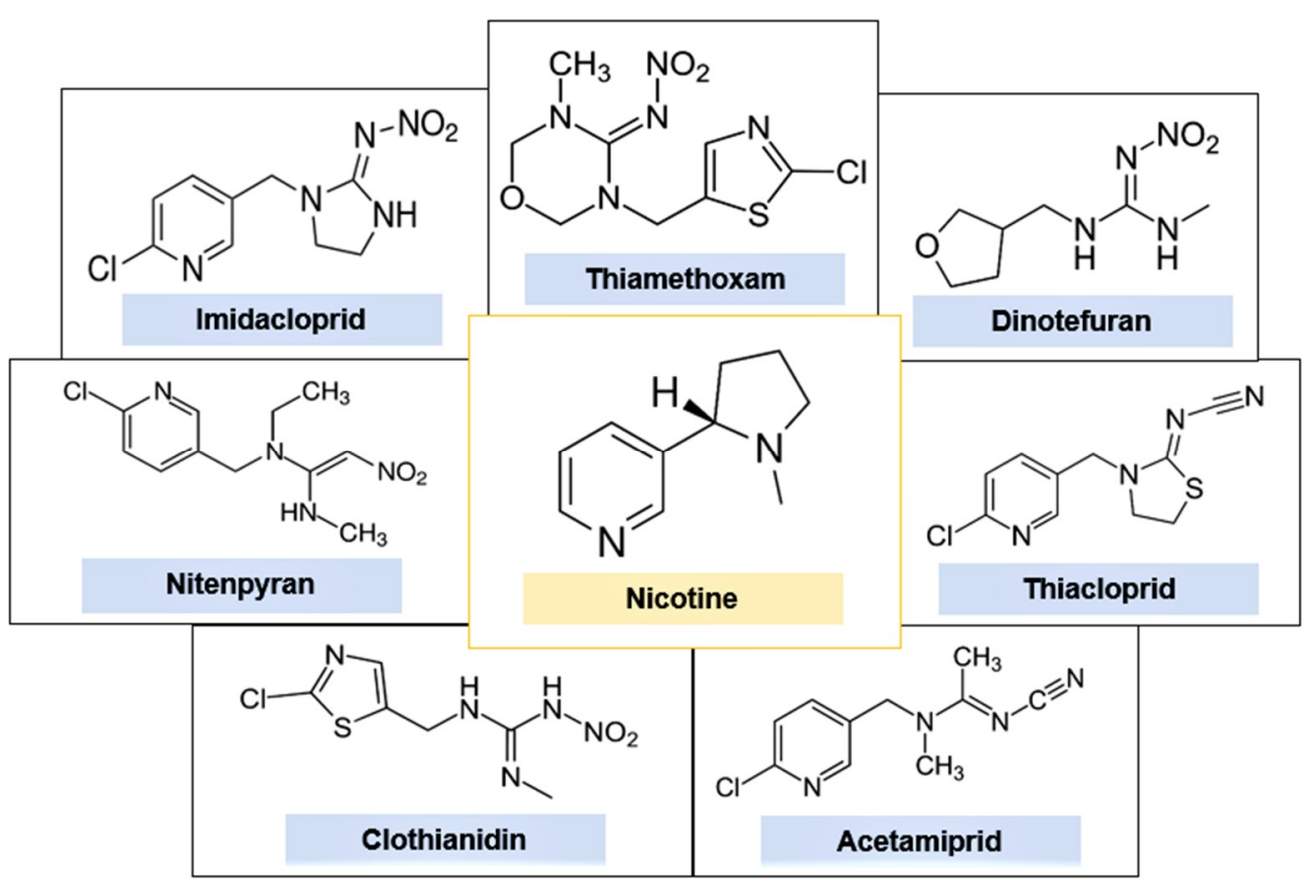

Figure 1. Chemical structures of nicotine and the neonicotinoid insecticides.

The low affinity of NNs for mammalian nAChRs and a presumed low penetration through the blood-brain barrier (BBB) has led to the consideration that this class of insecticides has a relatively low toxicity for this group of vertebrates, compared to older insecticides such as organophosphates or carbamates [12-14]. This has led to an increasingly frequent replacement of traditionally used insecticides by NNs, whose use is quite widespread [1].

However, although NNs were previously thought to have a short biological half-life, recent studies have shown that these insecticides can remain in the environment for periods ranging from 1 day to almost 19 years [15]. Thus, humans are continuously exposed to these pesticides, which can be absorbed through food or drinking water, by inhalation or dermal contact with occupational spray by-products, as well as by indoor air contamination following termite or pet pest control treatments $[4,16]$. In line with this, residues of NNs have been detected in a wide variety of foods and surface waters, which can pose a serious health problem for the animals and humans that consume them [16-26].

In recent decades, various adverse effects of NNs on the health of non-target organisms have been reported, which has led to reconsideration of the supposed low toxicity of this class of insecticides. In particular, toxic effects of $\mathrm{NN}$ insecticides on insects of economic importance, such as bees or bumblebees, have been documented [27-29]. It is for this reason that in 2018 the European Union banned the use of several NNs in outdoor activities for posing a high risk to bees [30].

Although it has been widely assumed that NNs act selectively on insect nAChRs and have virtually no affinity for vertebrate receptors, data published in the literature have seriously challenged this assumption. Thus, in vivo and in vitro exposure of various animal species to this class of pesticides has been associated with mutagenic, neurotoxic and immunotoxic effects, as well as reproductive toxicity and endocrine system disruption [31-40]. 
Likewise, numerous studies have corroborated the chronic exposure of humans to this class of pesticides by detecting the presence of NNs or their metabolites in urine samples from children and adults [41-43]. Epidemiological studies revealed that the detection rates and quantities of these pesticides detected in human biological samples have gradually increased over the last decade, in proportion to domestic use [44].

This continued exposure is particularly alarming since it has recently been shown that both NNs and some of their metabolites can also act as agonists of human nAChRs, which are widely distributed in the body [45]. Consequently, exposure to this class of pesticides has been associated with the appearance of a wide variety of clinical symptoms in humans, including headache, fatigue, convulsions, abdominal and chest pain, weakness, tremors, respiratory failure or memory loss, among others [46-51]. In some cases, exposure to large amounts of NNs has produced very serious damage, leading to the death of the intoxicated person [52-54].

Taken together, the above information shows that the increasing use of NN insecticides can be a major problem, not only at the environmental level, but also for human health Although NNs present low toxicity to non-target species, their presence in high quantities in all environments (soil, water, food) significantly increases the risk of exposure and toxicity to these species. The specific action of NNs on $\mathrm{nAChRs} \mathrm{seems} \mathrm{to} \mathrm{be} \mathrm{responsible}$ for most of the harmful effects that these substances can produce in humans and other mammals, although other possible mechanisms by which these pesticides produce their toxic effects on the nervous system have been investigated in recent years. Considering this information, in the present systematic review we investigate the available evidence of the last 10 years on the potential effects of NN pesticides on the nervous system of mammals. For this purpose, we analyze the main results obtained on the risks that exposure to this group of insecticides may cause to the structure and proper functioning of the nervous system of these non-target species.

\section{Methodology}

The present review was carried out with the objective of analyzing the results obtained in the most recent studies on the effects of NN pesticides on the mammalian nervous system. For this purpose, a systematic review was performed according to the guidelines established by Preferred Reporting Items for Systematic Reviews and Meta-Analyzes (PRISMA) [55]. The searches were carried out in the specialized databases PubMed, Scopus and Web of Science in May 2021, with a time restriction limited to studies published in the last ten years.

To identify the scientific articles that would be included in this review, the following search strategies were introduced in each of the databases: "((neonicotinoids) AND (nervous system) AND (mammals OR vertebrate OR rat))"; "((neonicotinoids) AND (mammals) AND (neurotoxic))"; “((neonicotinoids) AND (effect) AND (mammals))".

\section{Exclusion and Inclusion Criteria}

The articles included in this review met the following inclusion criteria: (1) original studies in article format; (2) in English or Spanish; (3) done in mammals; (4) studying the effects of the pesticide on the nervous system. Articles were excluded according to the following exclusion criteria: (1) theoretical articles or reviews and (2) studies in which NNs were administered in combination with other non-NN pesticides.

As a result of the searches carried out in the three databases, 678 articles published in the last ten years were identified. The articles were then exported to Refworks in order to eliminate those that were duplicated. In accordance with the inclusion and exclusion criteria, 466 titles and abstracts were screened to verify if they met the criteria previously mentioned. After this procedure, 423 articles were excluded for the reasons summarized in Figure 2. Finally, 38 articles were included in the present systematic review. 


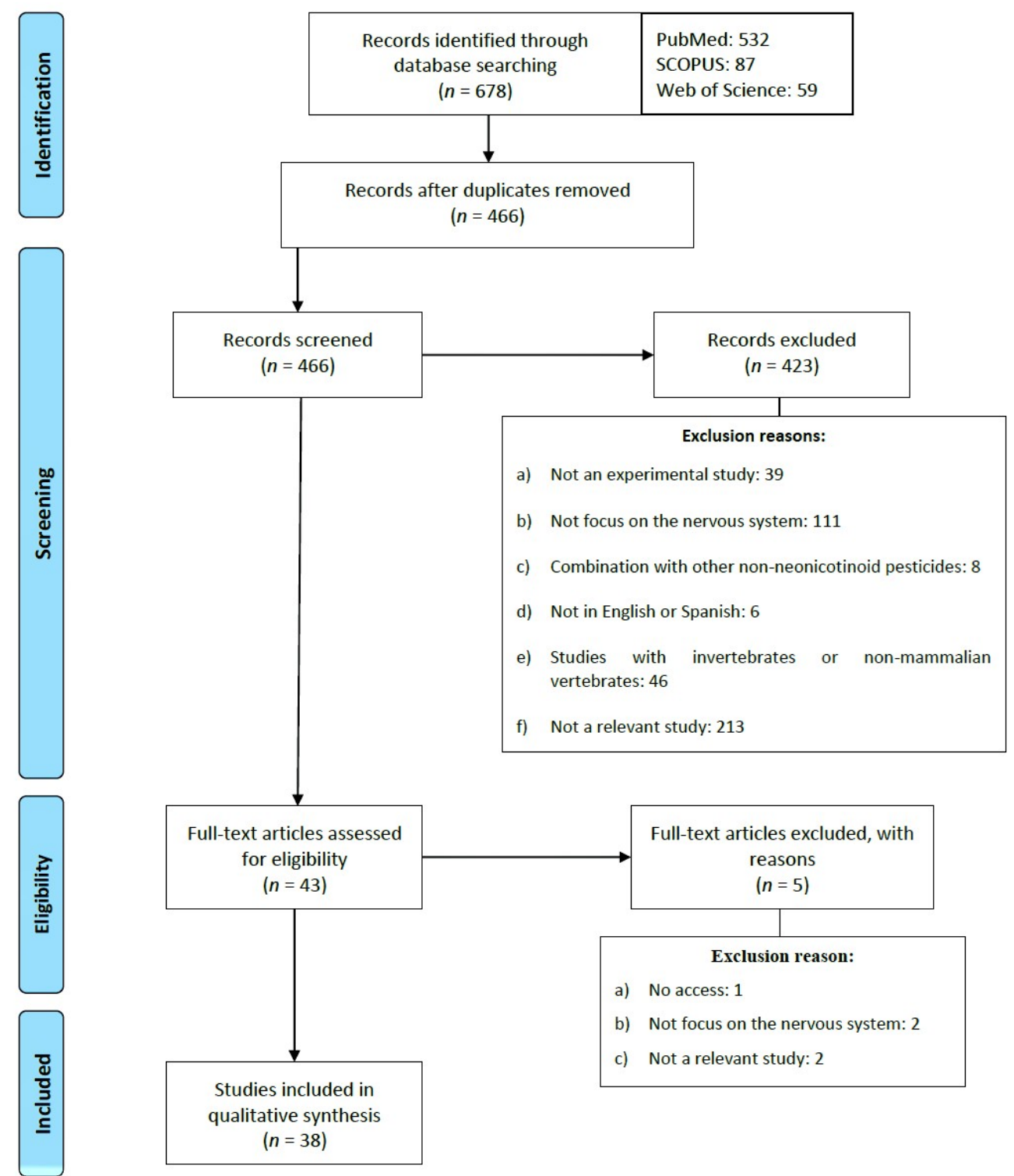

Figure 2. Flow diagram of the systematic search process.

\section{Results}

The studies that have been analyzed in the present review show that in vivo or in vitro exposure to $\mathrm{NN}$ pesticides can induce the appearance of a wide range of neurotoxic effects in the different mammalian species studied. In general, most of the information gathered in these investigations demonstrates the capacity of NNs to alter the structure of the nervous system and, consequently, its correct functioning, both during development and in adulthood.

\subsection{Effects of NNs on Rodents}

Most of the research included here focuses on the study of the neurotoxic effects exerted by NN pesticides on the CNS of rodents. The results described are summarized in Tables 1 and 2.

The toxic effects that NNs can produce in the brain depend on their ability to cross the $\mathrm{BBB}$, which is the protection system that controls the exchange of endogenous and exogenous substances between the blood and the extracellular environment of the brain [56]. The studies analyzed confirmed that NNs do cross the BBB, based on the detection of pesticides and their metabolites in the brains of exposed animals [15,57-60]. 
So, in the study by Hirano et al. [58], after the administration of $5 \mathrm{mg} / \mathrm{kg}$ of CLO, variable concentrations of the pesticide and its metabolites were found in the brain. The levels detected in the brain reached values of $0.2 \mathrm{ppm}$ in adult mice and almost $0.3 \mathrm{ppm}$ in aged mice, approximately $5 \%$ of the total dose administered. In this research, the levels of CLO and its metabolites found in the brain were higher in the group of elderly mice compared to the adult group, while the concentrations of some CLO metabolites in the urine were lower in the elderly group. These results suggest that, because of the lower metabolizing capacity during aging, there is a delay in the excretion of NNs in this age group, which could explain their higher concentration in brain tissue.

Similarly, in the research by Katić et al. [15] after treatment with IMI for 28 days with doses of $0.8 \mathrm{mg} / \mathrm{kg}$ and $2.25 \mathrm{mg} / \mathrm{kg}$, approximate levels of 0.3 and $0.5 \mu \mathrm{g} / \mathrm{g}$, respectively, were detected in the brain. Burke et al. [57] observed that the treatment of rats with $0.5 \mathrm{mg} / \mathrm{kg}$ of IMI during pregnancy and the early postnatal stage was associated with brain concentrations of pesticide of $1.18 \mathrm{pmol} / \mathrm{g}$ in mothers and $0.044 \mathrm{pmol} / \mathrm{g}$ in offspring. These data suggest that NNs could be transmitted from mothers to offspring through the placenta during pregnancy and/or breast milk during the postnatal stage.

On the other hand, in the study by Kapoor et al. [59] after a single administration of $20 \mathrm{mg} / \mathrm{kg}$ of IMI in rats, peak concentrations in the brain were detected $12 \mathrm{~h}$ after exposure. The levels detected were $0.5 \mu \mathrm{g} / \mathrm{g}$ for IMI and approximately $1.6 \mu \mathrm{g} / \mathrm{g}$ for its metabolite 6-chlorine nicotinic acid, which would be $2.5 \%$ and $8 \%$ of the total IMI administered to the animal, respectively. Likewise, the team of Shamsi et al. [60] administered doses of 10, 20 and $40 \mathrm{mg} / \mathrm{kg}$ of ACE for 28 days and detected concentrations in the hippocampus of 4.6, 5.9 and $7.3 \mu \mathrm{g} / \mathrm{g}$, respectively. In this study, it was also reported that the level of ACE in hippocampal tissue had increased in a dose-dependent manner after 28 days of treatment, suggesting its ability to bioaccumulate.

These studies show that NNs pesticides have the ability to cross the BBB reaching levels in brain tissue that can vary from $0.8 \%$ to $5 \%$ of the total dose administered. Although these studies are carried out under certain experimental conditions: with high doses, short treatment periods and limited to rodents, they are very useful for an estimation of the ability of NNs to cross the BBB of mammals. However, the mechanism by which these insecticides cross the BBB is unknown. In the study by Terayama et al. [61] the treatment with NNs did not alter the expression of cluster of differentiation 34 (CD34), which is a marker of vascular endothelial cells, one of the key cellular elements of the BBB. Previous studies have shown that CD34-positive cells can act to reduce BBB permeability [62], so it is possible that the increased permeability of the BBB to NNs is due to structural changes that do not necessarily involve endothelial cell involvement.

\subsubsection{Effects on Nervous System Development}

Once in the brain, NN pesticides can exert different toxic effects, which vary depending on the time of life when exposure occurs. It has been shown that, if exposure occurs during development, NN pesticides can alter the transcription of numerous genes essential for proper neurodevelopment [63,64]. Consequently, incomplete development or brain hypoplasia may occur, characterized by reduced neurogenesis and altered morphology and distribution of neurons [64-66]. However, the team of Kimura-Kuroda et al. [64] found no alterations in the number or morphology of immature neurons and glial cells after treatment with ACE and IMI insecticides.

On the other hand, Kara et al. [11] documented an increase in the expression of the muscarinic acetylcholine M1 receptor after IMI treatment. The M1 receptor appears to play a key role in neuronal development and plasticity in the cerebral cortex, reaching a transient peak of immunoreactivity during early development [67]. Therefore, this alteration in M1 receptor expression may result in the appearance of alterations in the structure and synapses of neurons located in the cerebral cortex. 


\subsubsection{Effects on Behavior and Cognitive Functions}

NN pesticides produce various types of behavioral and motor effects in animals exposed chronically or acutely, during the embryonic period or in adulthood. These effects may occur due to alterations in different neurotransmitter systems, but mainly the cholinergic, dopaminergic and glutamatergic systems, which are systems that interact with each other to regulate neuronal activity and behavior.

It has been shown that exposure to CLO or IMI during the gestational and lactation period was associated with various alterations in behavioral parameters in several generations of offspring $[57,68,69]$. Behavioral alterations were also observed in adolescent and adult rodents treated with IMI and CLO, in particular, deficits in motor behavior were described, especially in animals exposed to the highest doses of the pesticides [58,70,71].

NN pesticides have a close similarity to nicotine, a cholinergic agonist whose effects on behavior are well studied and documented. For this reason, authors tend to compare the effects produced by NNs with those derived from nicotine exposure. Accordingly, it has been observed that the effects of NNs on behavior were very similar to those produced by nicotine, in which exposure to this alkaloid caused a decrease, but not a complete loss, of locomotor activity [72,73]. Given these similarities in the effects observed, the authors hypothesize that the changes in motor behavior induced by NNs are due, as occurs with nicotine, to an action of these pesticides on the nAChRs present in dopaminergic neurons. However, the team of Yoneda et al. [74] observed that exposure to DIN for 6 weeks increased locomotor activity in a dose-dependent manner. These differences could be because DIN might be less toxic to rodents than other NN pesticides such as IMI and, therefore, produce weaker effects in these animals [75,76].

Concerning mood, although adult mice rarely squeak in the human audible range, they may emit audible calls in stressful and crisis situations [77]. In the research of Hirano et al. [78], acute exposure of mice to a single dose of CLO $(50 \mathrm{mg} / \mathrm{kg})$ led them to emit human-audible vocalizations $(4-16 \mathrm{kHz})$ as signs of excessive pesticide-induced stress or anxiety. Similarly, in this study the mice exhibited anxiety-like behavior. However, in the study by Yoneda et al. [74] chronic administration of various doses of the insecticide DIN did not produce significant changes in this behavior in mice.

As has been observed for locomotor behavior, the effects of NNs on anxiety were also compared with the effects produced by nicotine, which shows divergent results on anxiety levels in animals and humans. Thus, in some studies nicotine reduced both stress and anxiety [79-82], while in other investigations no effect was detected [83,84], and in other studies this compound even produced elevated levels of anxiety [85,86]. Like nicotine, NNs also seem to produce contradictory effects in the studies reviewed here. However, it is important to consider the differences in experimental design, doses used and treatment times, which differ between studies.

There is also discrepancy about the influence of $\mathrm{NN}$ pesticides on depressive behavior in rodents. While the team of Abd-Elhakim et al. [70] reported an increase in depression in animals after chronic treatment with IMI, Burke et al. [57] observed an antidepressant effect after early exposure to this pesticide. Similarly, Takada et al. [87] corroborated the antidepressant activity of the insecticide DIN after 5 weeks of exposure. These apparently contradictory results are like those observed in animals and humans exposed to nicotine in the short and long term [88-90] and are explained by considering the different sensitivities of nAChRs to agonists.

The cholinergic hypothesis of depression holds that depressive symptoms may arise as a result of cholinergic hyperactivity [91]. Therefore, the idea that, like nicotine, NN pesticides can produce antidepressant symptoms may be paradoxical, since they are cholinergic agonists. However, these observations can be reconciled by considering that these compounds, when chronically administered, can cause rapid and persistent desensitization of some nAChRs involved in mood regulation [92-94].

Specifically, nicotine is a desensitizing agent of $\alpha 4 \beta 2$ receptors and can produce a more potent and long-lasting desensitization of these receptors than acetylcholine itself [95]. 
Therefore, given the structural similarity with nicotine, it is to be expected that NNs are also capable of initially activating $\alpha 4 \beta 2$ receptors, but subsequently cause their desensitization and blockade when receptor stimulation is prolonged in time [96]. Thus, although it is probable that the antidepressant effect observed for some NNs is the result of the complex interaction of these compounds with different $n A C h R s$, part of this effect could be due to desensitization and blockade of the $\alpha 4 \beta 2$. Consistent with this hypothesis, previous studies have shown that blockade of brain $\alpha 4 \beta 2$ receptors, especially those located in the amygdala, could decrease depression-like symptoms [97,98].

On the other hand, in the study by Burke et al. [57] it was shown that early exposure of mice to $0.5 \mathrm{mg} / \mathrm{kg} /$ day of IMI caused a decrease in aggression and an improvement in social dominance. This result is also similar to those found in studies on the effects of nicotine in mammals [99-103]. Similarly, modulation of the aggressive effect could be mediated by the action of nicotine or NN compounds on $\beta 2$ receptors located in the prelimbic cortex [104].

Furthermore, chronic exposure to different doses of IMI or ACE altered learning and memory processes, especially in lactating rats $[11,60]$. This effect was similar to that observed with the exposure of animals and humans to nicotine $[105,106]$. These findings could be related to the essential role played by the cholinergic system in the hippocampus, the key brain structure in the processes of learning and memory formation [107].

In the hippocampus, the most abundant nicotinic receptor subtypes are $\alpha 7$ and $\alpha 4 \beta 2$ receptors [108]. Stimulation of $\alpha 7$ receptors triggers increased $\mathrm{Ca}^{+2}$ entry and activation of $\mathrm{Ca}^{+2}$-dependent signaling pathways that stimulate the release of glutamate. In this region, glutamate modulates synaptic plasticity and long-term potentiation, essential for learning and memory $[109,110]$. In line with this, it has been shown that exposure to NN pesticides decreases the expression of $\alpha 7$ receptors in the hippocampus [61]. Consequently, this is expected to severely affect the functioning of the hippocampal glutamatergic system, inducing changes, such as those observed in the study by Shamsi et al. [60], where treatment with ACE significantly reduced the levels of glutamate and its $N$-mehtyl-D-aspartate (NMDA)-like receptor subunits, which could translate into significant memory deficits.

It has also been shown that exposure to $\mathrm{NN}$ pesticides decreased neurogenesis in the dentate gyrus of the hippocampus and promoted apoptosis in this brain structure $[66,111,112]$. The dentate gyrus is one of the few brain areas where neurogenesis continues to occur during adulthood [113]. In addition, this region plays a fundamental role in various higher cognitive functions, such as learning and memory [114]. Therefore, the impairment caused by NN pesticides on the structure and function of the dentate gyrus could also cause the appearance of important learning and memory alterations.

\subsubsection{Changes in Neurotransmission}

Neurotransmission is another process that is altered by exposure to NN pesticides. Since these pesticides exert their neurotoxicity by acting on nAChRs, it is to be expected that the cholinergic neurotransmitter system is the most affected in mammals. This system plays a key role in the regulation of cognitive functions such as learning, memory and attention, and its dysregulation is associated with the development of various neurodegenerative diseases [115,116].

In line with the above, Kapoor et al. [59] and Vohra et al. [117] reported that both acute and chronic administration of IMI caused a significant inhibition in acetylcholinesterase (AChE) activity in the rodent brain, although no significant effects have been observed in other studies [15]. Because of this inhibition, acetylcholine is not degraded and accumulates in the synaptic cleft, where it remains for a longer period. Consequently, the accumulated neurotransmitter can stimulate the nAChRs to a greater extent, causing their opening and the influx of $\mathrm{Na}^{+}, \mathrm{K}^{+}$and $\mathrm{Ca}^{+2}$ ions across the membrane. Furthermore, as has been extensively demonstrated, the NNs can act as partial agonists of mammalian nAChRs, and thus may even compete with acetylcholine for binding to these receptors $[118,119]$. 
Therefore, an overstimulation of nAChRs by acetylcholine and/or NNs could cause a large influx of $\mathrm{Ca}^{+2}$ into the intracellular medium, such as that documented by KimuraKuroda et al. [120] in cerebellar neurons treated with ACE and IMI. $\mathrm{Ca}^{+2}$ is a universal intracellular messenger involved in the regulation of a wide range of activities, so that its intracellular levels are greatly reduced and tightly controlled [121]. Thus, any change in its cytosol levels can affect several processes, including neurotransmission, synaptic plasticity or gene transcription, among others [122,123].

Nitric oxide (NO) is an important physiological messenger synthesized by the enzyme nitric oxide synthase (NOS). There are at least three isoforms of this enzyme in the brain: the inducible NOS (iNOS), the endothelial NOS (eNOS), and the neuronal NOS (nNOS) $[124,125]$. Both eNOS and nNOS exhibit a mode of activation dependent on calmodulin binding to intracellular $\mathrm{Ca}^{+2}[126,127]$. Therefore, an increase in cytoplasmic levels of this ion induced by NNs can lead to activation of both NOS isoforms and subsequent cytotoxic release of NO, as observed in the study by Duzguner and Erdogan [128].

On the other hand, there is a generally accepted paradigm that states that overstimulation of membrane receptors leads to a reduction in their number in the cell membrane [129]. Therefore, this paradigm would explain how overstimulation of brain nAChRs by the agonist action of acetylcholine or NNs, can cause a decrease in the number of nAChRs in different brain regions, as demonstrated in the research of Terayama et al. [61]. However, the opposite results were obtained in animal and human studies chronically exposed to nicotine, as an increase in $\mathrm{nAChR}$ density (commonly known as upregulation) was observed [130]. Therefore, further research is needed to understand the effects of chronic exposure to NNs on both the number and functional status of nAChR receptors.

The interaction of $\mathrm{NN}$ insecticides with cholinergic receptors was also associated with alterations in the dopaminergic system. Dopaminergic neurons are involved in a wide range of functions, such as voluntary movement, motivated behavior, working memory or affectivity [131-133]. It has been shown that acute administration of CLO or IMI caused a marked increase in dopamine levels in the rat striatum [134-136]. In the study by Faro et al. [134] it was found that CLO-induced dopamine release was mainly mediated by an exocytotic-, vesicular-, and $\mathrm{Ca}^{+2}$-dependent mechanism. In their subsequent investigation, Faro et al. [135] concretized their results, demonstrating that CLO-induced striatal dopamine release requires activation of $\mathrm{nAChRs}$ possessing the $\alpha 4$ or $\alpha 7$ subunits, but not the $\beta 2$ subunit. This could be related to the fact that NNs, like acetylcholine, bind to the $\alpha$-subunits of nAChRs, whereas the other subunits act as regulators. Therefore, the administration of antagonists of $\alpha$-subunits will prevent the interaction of the pesticide with the receptor binding site and, consequently, blocks its effects on in vivo dopamine release. Likewise, Faro et al. [135] demonstrated that the increase in dopamine release also appears to depend on the activation of muscarinic acetylcholine receptors (mAChRs). On the other hand, the team of Abd-Elhakim et al. [70] found opposite results, as chronic exposure to the IMI for 60 days reduced the total dopamine content in brains from adult and adolescent rats.

Changes in dopamine release induced by exposure to NN pesticides could furthermore be related to changes in the transcription of the enzyme tyrosine hydroxylase (TH). TH is the rate-limiting enzyme of catecholamine synthesis and responsible for catalyzing the hydroxylation of tyrosine to L-3,4-dihydroxyphenylalanine (L-DOPA) [137]. Yoneda et al. [74] and Kawahata and Yamakuni [136] have found that in vivo and in vitro administration of NNs, both short- and long-term, enhanced transcription and increased phosphorylation of brain $\mathrm{TH}$, which was associated with an increase in its activity. In this regard, Kawahata and Yamakuni [136] found that the insecticide IMI facilitated TH transcription by acting as a partial agonist at $\alpha 3 \beta 4$ and $\alpha 7$ receptors. Because of its interaction with these receptors, it is considered that IMI could cause long-term activation of intracellular signaling of both cAMP response element-binding protein (CREB) and protein kinase A (PKA)/extracellular signal-regulated kinase (ERK) and Rho cascade. Activation of these signaling cascades could facilitate $\mathrm{TH}$ transcription and expression of the phenylethanolamine 
$\mathrm{N}$-methyltransferase (PNMT) gene, the enzyme that catalyzes epinephrine biosynthesis, leading to up-regulated catecholamine production and secretion.

On the other hand, exposure to NNs also affected the functioning of the glutamatergic neurotransmitter system. Glutamate is the main excitatory neurotransmitter in the CNS and plays critical roles in learning, memory and cognition $[138,139]$. Both excessive glutamate release and glutamatergic dysfunction are associated with multiple neurodegenerative diseases and psychiatric disorders [140,141]. In the study by Shamsi et al. [60] it was observed that exposure to the pesticide ACE for 28 days significantly reduced glutamate levels in the hippocampus of the treated subjects. In addition, treatment with the highest doses of ACE (20 or $40 \mathrm{mg} / \mathrm{kg}$ ) caused a decrease in the expression of NR1, NR2A and NR2B genes. These genes encode the subunits that make up the NMDA ionotropic glutamatergic receptors, which are ligand-activated cation channels that allow $\mathrm{Ca}^{+2}$ and $\mathrm{Na}^{+}$to enter and $\mathrm{K}^{+}$to exit the cell [139,142].

Other systems that suffered alterations after exposure to NNs were the serotonergic and GABAergic systems. On the one hand, the serotonergic system is one of the oldest neurotransmitter systems in the brain and plays a key role in mood regulation, as well as participating in other basic biological functions including appetite, sleep and cognitive function $[143,144]$. The GABAergic neurotransmitter system is fundamental for the neurogenesis processes in the developing CNS, while in the mature CNS it is involved in functions such as the regulation of neuronal responsiveness, the maintenance of the excitation/inhibition balance and neuronal plasticity $[145,146]$. Changes in any of these neurotransmitter systems has been related to various pathologies, such as schizophrenia due to deficient functioning of the GABAergic system, or depression in the case of abnormalities in the serotonergic system $[147,148]$.

In line with the above, Abd-Elhakim et al. [70] have reported that exposure to IMI for 60 days significantly reduced GABA and serotonin levels in the brain of adolescent and adult rats. However, in the study by Takada et al. [87], treatment with DIN for 5 weeks was not associated with a decrease in the number of serotonergic neurons. These differences are possibly linked to differences between studies, as the experimental designs differed in the type, amount, exposure time, and animal species. Therefore, further studies are needed to clarify this controversy regarding the effects of NN compounds on serotonergic neurotransmission.

\subsubsection{Induction of Oxidative Stress}

Oxidative stress is one of the mechanisms by which pesticides can exert their toxicity $[149,150]$. Oxidative stress occurs when the production of reactive oxygen species (ROS) or nitrogen species exceeds the capacity of the body's antioxidant system to scavenge them [151]. As a consequence of the overproduction of free radicals, lipid peroxidation (LPO), DNA damage, and extensive protein oxidation occur, leading to cellular degeneration $[151,152]$. The brain, with its high lipid content, high oxygen consumption and reduced antioxidant capacity, is particularly susceptible to oxidative stress [153,154].

Exposure to NNs has been associated with an increase in ROS levels and, consequently, LPO, oxidative damage to genetic material and protein oxidation $[70,128,155,156]$. In particular, an increase was observed in the levels of malondialdehyde (MDA), 8hydroxyguanosine and protein carbonyl, which were used as markers of LPO, DNA oxidation and protein oxidation, respectively $[70,156]$.

To counteract the overproduction of ROS, the body is provided with a natural antioxidant system formed by a set of endogenous antioxidant enzymes and other non-enzyme compounds. In addition, this system is reinforced by exogenous antioxidants obtained through the diet $[157,158]$. Together, both endogenous and exogenous antioxidants aim to minimize the levels of ROS, while at the same time ensuring the presence of sufficient levels of these molecules to perform cell signaling and redox regulation functions [159,160].

It has been shown that exposure to NNs for approximately one month caused an increase in the activity of the enzymes catalase (CAT) and glutathione peroxidase (GSH-Px) 
in the brain $[15,128]$. However, a longer treatment with NNs decreased the antioxidant capacity, decreasing the activity of these two antioxidant enzymes $[70,156]$. These results suggest that, although in the short term these antioxidant defense systems attempt to counteract the intense generation of ROS induced by NNs, when this overproduction is maintained over time there is a depletion of these protective molecular systems. On the other hand, during long-term exposure to the pesticide ACE, there was an increase in superoxide dismutase (SOD) and glutathione-S-transferase (GST) activity in the mitochondrial matrix [156]. These data suggest that these enzymes maintain their activity over time in an attempt to reduce excessive ROS levels and remove the end products of LPO.

Glutathione (GSH) is another endogenous antioxidant that plays an important role in the detoxification of ROS [161]. GSH has a strong ability to interact with ROS and neutralize them, making it a potent antioxidant [162]. The studies included here have shown that chronic exposure to NNs for 1 or 6 months resulted in a significant decrease in GSH levels $[128,156]$, suggesting that GSH depletion could take place already at the early stages of pesticide exposure and would no longer recover over time.

Xanthine oxidase is an enzyme that is widely distributed in various mammalian tissues, including the brain [163]. This enzyme is involved in the oxidation of a wide variety of endogenous and exogenous substrates, such as purines or ethanol. As a result of its activity, xanthine oxidase increases ROS levels by generating superoxide radicals and hydrogen peroxide [164-166]. In line with this, in the study by Duzguner and Erdogan [128], exposure to IMI caused an increase in xanthine oxidase activity, which, consequently, could contribute to increased cellular oxidative stress through the production of ROS.

The mitochondria are the main ATP producing center in cells, and during the process of synthesis of these molecules a certain amount of free radicals, considered physiological, are generated [167]. Under conditions of oxidative stress, mitochondria become one of the main targets of ROS damage, which can induce mutations in mitochondrial DNA, alter their antioxidant defense systems, damage the mitochondrial respiratory chain, affect membrane permeability or influence $\mathrm{Ca}^{+2}$ homeostasis [168]. Some of the studies analyzed here show that the exposure to $\mathrm{NN}$ pesticides could induce several of these alterations in the rodent CNS neurons.

It has been shown that treatment with NN pesticides increased mitochondrial membrane permeability $[155,156]$. These changes could be due to the mitochondrial membrane LPO induced by ROS. Another change observed was the reduction in the mitochondrial membrane potential [155]. Since mitochondria act as reservoirs of $\mathrm{Ca}^{+2}$ ions, excessive generation of ROS can trigger the release of these ions into the cytosol. The increase in $\mathrm{Ca}^{+2}$ levels also change the mitochondrial potential that leads to the production of superoxide radicals, thus initiating a vicious circle [168].

Thus, in the situation of oxidative stress caused by exposure to NN pesticides, the mitochondrial antioxidant defense systems are insufficient to counteract the oxidative damage. So, the excessive ROS can attack the lipids of the mitochondrial membranes, causing prolonged opening of the mitochondrial permeability transition pore and altering the mitochondrial membrane potential $[169,170]$. As a consequence, the structure of these organelles is severely damaged leading to mitochondrial dysfunction and a drop in the rate of oxygen consumption, as observed in the study by Gasmi et al. [156].

\subsubsection{Induction of Inflammation}

The inflammatory process plays an essential role in helping the immune system to counteract pathological states such as infection, but when inflammation becomes unbalanced or prolonged over time it can lead to progressive tissue damage [171]. In the CNS, the inflammatory response is mediated by the release of cytokines, chemokines, secondary messengers and ROS [172]. Most of these mediators are synthesized and released by microglia and astrocytes in the CNS [173]. Thus, when an insult occurs due to the action of neurotoxic substances such as pesticides, the microglial cells are activated and no longer exhibit a branched morphology but rapidly manifest an amoeboid phenotype $[174,175]$. 
Likewise, the astrocytes also become reactive in response to insults and there is an upregulation of glial fibrillary acidic protein (GFAP), which is the main component of the intermediate filaments of the astrocytes [176].

Activation of microglia involves a series of functional and morphological changes in these cells. Two main polarization states or phenotypes have been described and that show opposite characteristics: the M1 cytotoxic-proinflammatory phenotype or the M2 cytoprotective-anti-inflammatory phenotype $[177,178]$. M1 or cytotoxic microglia produces ROS and proinflammatory cytokines, increasing tissue injury and creating an adverse environment for neuroprotection [179]. In contrast, activation to the M2 phenotype is related to the production of growth factors and anti-inflammatory cytokines that stimulate tissue regeneration [180].

Some of the studies reviewed here have shown that exposure to NN pesticides can trigger an extensive inflammatory process. Thus, in response to CNS insult, astrocytes became more reactive, evidenced by a marked increase in GFAP levels [70]. Similarly, microglia acquired an amoeboid morphology and increased expression of its marker Iba1, which is a hallmark of the activation of this cell type $[65,66]$. This glial activation was related to the increased release of the proinflammatory cytokines interleukin 1beta (IL-1 $\beta$ ), interleukin 6 (IL-6), tumor necrosis factor alpha (TNF- $\alpha$ ), and interferon gamma (IFN- $\gamma$ ), observed in the study by Duzguner and Erdogan [128]. However, in this same study there was a decrease in the levels of the cytokine interleukin 12 (IL-12), also a promoter of the inflammatory process. Taken together, these results suggest that exposure to NN pesticides promotes microglial polarization to the M1 cytotoxic phenotype, which could promote neurotoxicity by inducing excessive release of proinflammatory cytokines, as observed in the studies of Kagawa and Nagao [65] and Nakayama et al. [66].

Another process that takes place during neuroinflammation is the activation of iNOS, which is expressed in several cell types, including microglia, astrocytes and CNS neurons [181]. This enzyme is responsible for the production of NO, which plays an important role as a neurotransmitter and neuromodulator in the CNS [182]. The expression of iNOS in the CNS is tightly regulated, although various intrinsic and extrinsic stimuli can induce its activity [181]. In this regard, it has been shown that, during the inflammatory response, some cytokines such as IFN- $\gamma$ can activate signaling pathways that stimulate iNOS activity and NO production $[183,184]$. However, excessive stimulation of iNOS can lead to massive production of $\mathrm{NO}$ and NO-derived peroxynitrate, which contribute greatly to oxidative stress [185]. The results of the study by Duzguner and Erdogan [128] demonstrated that exposure to IMI enhanced iNOS mRNA transcription and consequently led to a significant increase in NO production.

\subsubsection{Effects on Energy Metabolism}

In addition to the alterations mentioned in the previous sections, exposure to NNs was also associated with alterations in the metabolism of brain cells. The brain is an organ with an unusually high metabolic demand, since it represents only $2 \%$ of the body mass, it uses approximately $20 \%$ of the total glucose and oxygen of the human organism [186]. Thus, strict regulation of cellular energy metabolism is essential to ensure normal brain function, and any alteration in this can be associated with the development of various pathologies $[187,188]$. Some in vitro and in vivo investigations have shown that both shortand long-term exposure to IMI and CLO pesticides altered the metabolism and energy balance of rodent brain cells, especially in the hippocampus [112,189]. These changes could reflect the metabolic plasticity of brain cells, that is, an attempt by brain cells to adapt their metabolism to the adverse conditions generated by NN pesticides. However, these significant alterations may potentially contribute to neuronal dysfunction and induce apoptosis [190]. 
Table 1. Neurotoxic effects derived from in vivo exposure to neonicotinoid pesticides in rodents.

\begin{tabular}{|c|c|c|c|c|}
\hline Species & $\begin{array}{l}\text { Dose and Time } \\
\text { Exposition }\end{array}$ & Objectives & Results & Reference \\
\hline Wistar rats & $\begin{array}{l}\text { IMI: } 0.5,2 \text { or } \\
8 \mathrm{mg} / \mathrm{kg} / \text { day orally } \\
\text { for } 3 \text { months }\end{array}$ & $\begin{array}{l}\text { Evaluate the effects of different } \\
\text { doses of IMI on learning and } \\
\text { memory in infant and adult rats }\end{array}$ & $\begin{array}{l}\text { - Treatment with } 2 \text { and } 8 \mathrm{mg} / \mathrm{kg} \text { induced a decrease in learning in infant rats and } \\
\text { with the } 8 \mathrm{mg} / \mathrm{kg} \text { dose in adult rats } \\
\text { - } \quad \text { Increased M1 receptor expression at doses of } 2 \text { and } 8 \mathrm{mg} / \mathrm{kg} \text { in adult rats. }\end{array}$ & [11] \\
\hline Wistar rats & $\begin{array}{l}\text { IMI: } 0.06,0.8 \text { or } \\
2.25 \mathrm{mg} / \mathrm{kg} / \text { day } \\
\text { orally for } 28 \text { days }\end{array}$ & $\begin{array}{l}\text { Investigate the effects of IMI on } \\
\text { cholinesterase activities, oxidative } \\
\text { stress biomarkers and primary DNA } \\
\text { damage in blood and brain tissue }\end{array}$ & $\begin{array}{l}\text { - There were no alterations in total cholinesterase, AChE or butyrylcholinesterase } \\
\text { activity in the brain } \\
\text { - There was no change in CAT and SOD activity, but there was an increase in } \\
\text { GSH-Px activity } \\
\text { - Presence of IMI in brain tissue of animals treated with the two highest doses } \\
\text { - } \quad \text { Dose-dependent neuronal DNA damage }\end{array}$ & [15] \\
\hline Wistar rats & $\begin{array}{l}\text { IMI: } 20 \mathrm{mg} / \mathrm{kg} \text { orally } \\
\text { Single dose }\end{array}$ & $\begin{array}{l}\text { Evaluate pharmacokinetic and } \\
\text { pharmacodynamic responses after } \\
\text { single oral exposure }\end{array}$ & $\begin{array}{l}\text { - The maximum concentration of IMI and its metabolites in the brain was observed } \\
\text { at } 12 \mathrm{~h} \text { after exposure } \\
\text { - Inhibition of brain AChE at } 6-48 \mathrm{~h} \text { after administration }\end{array}$ & [59] \\
\hline Wistar rats & $\begin{array}{l}\text { IMI: } 10 \text { or } \\
20 \mathrm{mg} / \mathrm{kg} / \text { day orally } \\
\text { for } 60 \text { days }\end{array}$ & $\begin{array}{l}\text { Assess the alterations induced by } \\
\text { IMI in the biochemical, } \\
\text { histopathological and protein } \\
\text { profile in plasma and brain }\end{array}$ & - $\quad$ Decreased brain AChE activity & [117] \\
\hline Wistar rats & $\begin{array}{l}\text { IMI: } 1 \mathrm{mg} / \mathrm{kg} / \text { day } \\
\text { orally for } 30 \text { days }\end{array}$ & $\begin{array}{l}\text { Assess the effects of chronic } \\
\text { exposure to IMI on the induction of } \\
\text { oxidative stress and inflammation }\end{array}$ & $\begin{array}{ll}- & \text { Increased NO production } \\
- & \text { Improved transcription of iNOS, eNOS and nNOS mRNA } \\
- & \text { Increase in LPO } \\
- & \text { Increased activity of xanthine oxidase } \\
- & \text { Increased CAT activity and decreased GSH levels } \\
- & \text { Increased expression of TNF- } \alpha, \text { IL-1 } \beta, \text { IL- } 6, \text { and IFN- } \gamma, \text { but decreased IL-12 }\end{array}$ & [128] \\
\hline Sprague-Dawley rats & $\begin{array}{l}\text { IMI: } 1 \mathrm{mg} / \mathrm{kg} / \text { day } \\
\text { orally for } 60 \text { days }\end{array}$ & $\begin{array}{l}\text { Evaluate the effects of IMI on } \\
\text { neurobehavioral performance, } \\
\text { oxidative stress and the induction of } \\
\text { apoptosis in the brain of adult or } \\
\text { adolescent rats }\end{array}$ & $\begin{array}{ll}\text { - } & \text { Less exploratory activity, deficit of sensorimotor functions and depression } \\
\text { - } & \text { Reduction of serotonin, GABA and dopamine } \\
\text { - } & \text { Increase in the levels of protein carbonyl, 8-hidroxyguanosine and MDA, but } \\
\text { - } & \text { reduction in the total antioxidant capacity } \\
\text { - } & \text { Increased degeneration } \\
\text { - } & \text { Increase in Bax levels and decrease in Bcl-2 levels }\end{array}$ & [70] \\
\hline
\end{tabular}


Table 1. Cont.

\begin{tabular}{|c|c|c|c|c|}
\hline Species & $\begin{array}{l}\text { Dose and Time } \\
\text { Exposition }\end{array}$ & Objectives & Results & Reference \\
\hline Sprague-Dawley rats & $\begin{array}{l}\text { IMI: } 0.5 \text { or } \\
1 \mathrm{mg} / \mathrm{kg} / \text { day orally } \\
\text { for } 60 \text { days }\end{array}$ & $\begin{array}{l}\text { Study the effects of IMI on stress by } \\
\text { assessing cortisone and } \\
\text { catecholamine levels, with a focus } \\
\text { on behavioral alterations }\end{array}$ & - $\quad$ Behavioral deficits, particularly at the highest dose of IMI & [71] \\
\hline CD-1 mice & $\begin{array}{l}\text { IMI: } 0.5 \mathrm{mg} / \mathrm{kg} / \text { day } \\
\text { infusion through an } \\
\text { osmotic pump } \\
\text { From GD4 until PND21 }\end{array}$ & $\begin{array}{l}\text { Assess the effects of IMI after an } \\
\text { intrauterine and early postnatal } \\
\text { exposure }\end{array}$ & $\begin{array}{l}\text { - The offspring of mothers treated with IMI showed elevated motor activity, } \\
\text { improved social dominance, reduced depressive behavior and a decrease in } \\
\text { social aggression } \\
\text { - Low levels of IMI were detected in the brains of treated mothers and traces of } \\
\text { the pesticide in the brains of some pups after exposure to weaning }\end{array}$ & [57] \\
\hline KM mice & $\begin{array}{l}\text { IMI: } 5 \text { or } \\
20 \mathrm{mg} / \mathrm{kg} / \text { day orally } \\
\text { for } 28 \text { days }\end{array}$ & $\begin{array}{l}\text { Examine the histopathological, } \\
\text { biochemical and metabolic } \\
\text { alterations induced by IMI in the } \\
\text { hippocampus and liver }\end{array}$ & $\begin{array}{l}\text { - } \quad \text { Hippocampal damage in animals treated with the highest dose } \\
\text { - } \quad \text { Alteration in the metabolic profile in the hippocampus at both doses }\end{array}$ & [112] \\
\hline Wistar rats & $\begin{array}{l}\text { ACE: } 10,20 \text { or } \\
40 \mathrm{mg} / \mathrm{kg} / \text { day orally } \\
\text { for } 28 \text { days }\end{array}$ & $\begin{array}{l}\text { Investigate the effect of ACE on } \\
\text { spatial memory and the } \\
\text { vulnerability of the hippocampal } \\
\text { glutamatergic system }\end{array}$ & $\begin{array}{l}\text { - } \quad \begin{array}{l}\text { Alteration of learning, consolidation and memory retrieval processes, } \\
\text { especially at the highest doses }\end{array} \\
\text { - } \quad \text { Dose-dependent increase of pesticide concentration in the hippocampus } \\
\text { - } \quad \text { Neuronal degeneration and apoptosis in the dentate gyrus } \\
\text { - } \quad \text { Reduced glutamate levels } \\
\text { Reduced expression of NR1, NR2A and NR2B genes after exposure to the } \\
\text { intermediate dose of ACE }\end{array}$ & {$[60]$} \\
\hline Wistar rats & $\begin{array}{l}\text { ACE: } 3.14 \mathrm{mg} / \mathrm{kg} / \text { day } \\
\text { orally for } 6 \text { months }\end{array}$ & $\begin{array}{l}\text { Assess the effects of ACE on } \\
\text { membrane integrity and } \\
\text { mitochondrial potential }\end{array}$ & $\begin{array}{ll}\text { - } & \text { Decreased GSH levels and GSH-Px and CAT activities in mitochondria } \\
\text { - } & \text { Increased GST and SOD activity in the mitochondrial matrix } \\
\text { - } & \text { Increased levels of MDA } \\
\text { - } & \text { Increased membrane permeability and mitochondrial swelling and significant } \\
\text { decrease in mitochondrial respiration }\left(\mathrm{O}_{2} \text { consumption }\right)\end{array}$ & [156] \\
\hline A/J mice & $\begin{array}{c}\text { ACE: } 71 \text { or } \\
710 \mu \mathrm{g} / \mathrm{g} / \text { day orally } \\
\text { for } 3 \text { and } 7 \text { days }\end{array}$ & $\begin{array}{l}\text { Investigate the accumulation of } \\
\text { ACE and expression of } \mathrm{nAChRs} \text { in } \\
\text { different areas of the brain }\end{array}$ & $\begin{array}{l}\text { - Treatment with the pesticide produced no effects on the histology or on the } \\
\text { expression of CD34 } \\
\text { - } \quad \text { Presence of higher concentrations of ACE in the midbrain } \\
\text { - Decreased expression of nAChRs, especially those of the } \beta 2 \text { subtype, in various } \\
\text { brain regions of animals treated for } 7 \text { days with the highest dose of ACE }\end{array}$ & [61] \\
\hline
\end{tabular}


Table 1. Cont

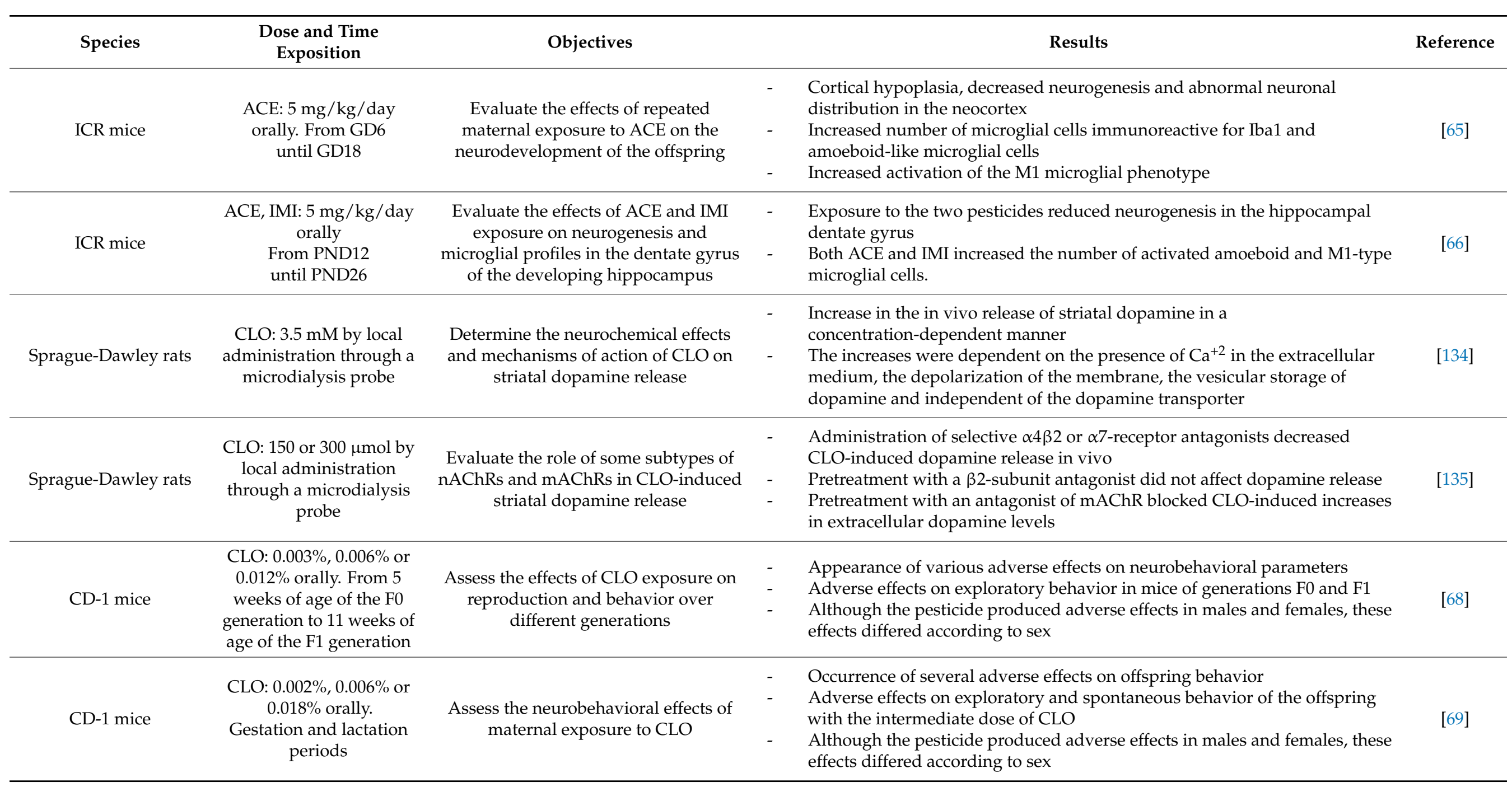


Table 1. Cont.

\begin{tabular}{|c|c|c|c|c|}
\hline Species & Dose and Time Exposition & Objectives & Results & Reference \\
\hline C57BL/6J mice & $\begin{array}{l}\text { CLO: } 5 \mathrm{mg} / \mathrm{kg} \text { orally } \\
\quad \text { Single dose }\end{array}$ & $\begin{array}{l}\text { Investigate the role of aging in CLO-induced } \\
\text { behavioral effects }\end{array}$ & $\begin{array}{l}\text { - Decreased locomotor activity in aged mice, but not in adult mice } \\
\text { - } \quad \text { Higher concentrations of CLO and its metabolites in the brains of } \\
\text { aged mice than in adult mice }\end{array}$ & [58] \\
\hline C57BL/6N mice & $\begin{array}{l}\text { CLO: } 5 \text { or } 50 \mathrm{mg} / \mathrm{kg} \text { orally } \\
\text { Single dose }\end{array}$ & $\begin{array}{l}\text { Evaluate the neurobehavioral effects of CLO } \\
\text { and explore the brain regions targeted by } \\
\text { neonicotinoids in mammals }\end{array}$ & $\begin{array}{l}\text { - Induction of audible vocalizations }(4-16 \mathrm{kHz}) \text { for highest dose } \\
\text { - } \quad \text { Anxiety-like behavior }\end{array}$ & [78] \\
\hline C57BL/6N mice & $\begin{array}{l}\text { DIN: } 100,500 \text { or } \\
2500 \mathrm{mg} / \mathrm{kg} / \text { day orally for } \\
6 \text { weeks }\end{array}$ & $\begin{array}{l}\text { Analyze the biochemical and behavioral effects } \\
\text { of DIN exposure during the peripubertal } \\
\text { period on the nigrostriatal pathway }\end{array}$ & $\begin{array}{l}\text { - Increased locomotor activity in a dose-dependent manner, but no } \\
\text { change in anxiety-like behavior } \\
\text { - Increased TH expression in the substantia nigra. }\end{array}$ & [74] \\
\hline C57BL/6NCrSlc mice & $\begin{array}{l}\text { DIN: } 100,500 \text { or } \\
2500 \mathrm{mg} / \mathrm{kg} / \text { day orally for } \\
5 \text { weeks }\end{array}$ & $\begin{array}{l}\text { Investigate the relationship between } \\
\text { subchronic DIN exposure and a } \\
\text { depression-related phenotype }\end{array}$ & $\begin{array}{l}\text { - } \quad \text { Antidepressant activity was observed in the tail suspension test } \\
\text { - } \quad \text { No decrease in the number of serotonergic cells was observed }\end{array}$ & [87] \\
\hline
\end{tabular}


Table 2. Neurotoxic effects observed after in vitro exposure to neonicotinoid pesticides in rodents.

\begin{tabular}{|c|c|c|c|c|}
\hline Cellular Line & $\begin{array}{l}\text { Dose and Time of } \\
\text { Exposure }\end{array}$ & Objective & Results & Reference \\
\hline $\begin{array}{l}\text { Neuron-enriched cultures } \\
\text { from neonatal rat cerebellum }\end{array}$ & ACE, IMI: $1 \mu \mathrm{M}$ for 14 days & $\begin{array}{l}\text { Examine the neurotoxic effects of } \\
\text { long-term and low-dose exposure } \\
\text { on cultures enriched with } \\
\text { cerebellar neurons }\end{array}$ & $\begin{array}{l}\text { - } \quad \begin{array}{l}\text { There were no alterations in the number or morphology of immature } \\
\text { neurons or glial cells } \\
\text { - }\end{array} \text { Altered dendritic arborization of Purkinje cells after treatment with NNs } \\
\text { - } \quad \text { IMI and ACE altered expression of genes essential for neurodevelopment }\end{array}$ & [64] \\
\hline $\begin{array}{l}\text { Primary cultures of } \\
\text { cerebellar neurons from } \\
\text { neonatal rats }\end{array}$ & ACE, IMI: 1,10 or $100 \mu \mathrm{M}$ & $\begin{array}{l}\text { Determine the effects of the two } \\
\text { NNs on neuronal nAChRs and } \\
\text { compare their effects with nicotine }\end{array}$ & $\begin{array}{l}\text { All ACE and IMI concentrations used caused increases in } \mathrm{Ca}^{+2} \text { influx into } \\
\text { cerebellar neurons (mainly granule cells) }\end{array}$ & [120] \\
\hline PC12 cells & $\begin{array}{l}\text { IMI, ACE, CLO, TMX: } \\
1-100 \mu \mathrm{M} \text { for } 5 \text { days }\end{array}$ & $\begin{array}{l}\text { Evaluate the neurotoxic effects on } \\
\text { the development of several } \\
\text { commonly used pesticides }\end{array}$ & $\begin{array}{l}\text { - IMI showed a dose-dependent inhibitory effect on neurite outgrowth. } \\
\text { ACE }(10 \mu \mathrm{M}) \text { produced significant alterations in the transcription of } \\
\text { genes related to the development of the nervous system. }\end{array}$ & [63] \\
\hline PC12 cells & $\begin{array}{l}\text { IMI: } 1,3,30 \text { or } 100 \mu \mathrm{M} \text { for } \\
24 \text { and } 48 \mathrm{~h}\end{array}$ & $\begin{array}{l}\text { Assess the effects of IMI on the } \\
\text { catecholaminergic function of } \\
\text { chromaffin cells }\end{array}$ & $\begin{array}{l}\text { - IMI improved the synthesis of catecholamines by increasing the } \\
\text { expression of the genes that synthesize TH and PNMT } \\
\text { IMI facilitated this transcription by acting as a partial agonist of the } \alpha 3 \beta 4 \\
\text { and } \alpha 7 \mathrm{nAChR} \text { subtypes that, when activated, induced a long-term } \\
\text { activation of the intracellular signaling pathways PKA/CREB and RhoA }\end{array}$ & [136] \\
\hline PC12 cells & ACE: $100-700 \mu \mathrm{M}$ for $24 \mathrm{~h}$ & $\begin{array}{l}\text { Investigate the toxic effects of } \\
\text { ACE on PC12 cells }\end{array}$ & $\begin{array}{ll}\text { - } & \text { Increased cell death by apoptosis } \\
\text { - } & \text { Increased ROS and LPO levels } \\
\text { - } & \text { Reduction in mitochondrial membrane potential } \\
\text { - } & \text { Dose-dependent increase in DNA damage }\end{array}$ & [155] \\
\hline NSPC y N2a & $\begin{array}{l}\text { IMI, CLO: } 0-4000 \mu \mathrm{M} \text { for } \\
48 \mathrm{~h}\end{array}$ & $\begin{array}{l}\text { Investigate the toxic effects and } \\
\text { metabolic changes induced by IMI, } \\
\text { CLO and their mixture in } \\
\text { cell cultures }\end{array}$ & $\begin{array}{l}\text { - Alteration in metabolism and energy balance of NSPCs with both } \\
\text { insecticides alone or mixed }\end{array}$ & [189] \\
\hline
\end{tabular}

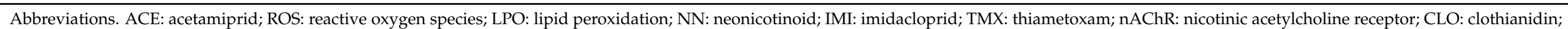

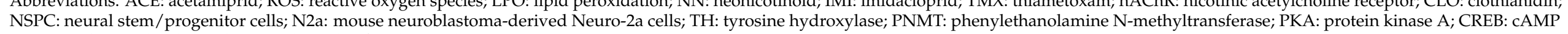
response element-binding; RhoA: ras homolog family member $\mathrm{A}$. 


\subsubsection{Induction of Apoptosis}

Conditions of oxidative stress and neuroinflammation, mitochondrial damage, alterations in neurotransmitter systems, as well as changes in energy metabolism induced by $\mathrm{NN}$ pesticides can eventually lead to neuronal death. Some of the studies included here agree that both acute and chronic treatment with IMI and ACE pesticides caused DNA damage and neuronal degeneration, especially affecting the hippocampus $[15,60,70,112,155]$.

Of the neurogenic regions in the adult CNS, it is the hippocampus that receives the most attention, since during hippocampal neurogenesis new granular cells are generated in the dentate gyrus, which are essential for the correct functioning of higher cognitive processes, such as memory or mood regulation [191,192]. Thus, a dysregulation in neurogenesis in the adult hippocampus has been linked to the development of various neurological diseases such as Alzheimer's disease and mood disorders [193,194]. In line with this, Nakayama et al. [66] have observed that early exposure to ACE or IMI reduced neurogenesis in the dentate gyrus of the hippocampus in mice. Similarly Shamsi et al. [60] demonstrated that ACE exposure induced significant neuronal degeneration and apoptosis in this region.

Although there are different modes by which cell death can occur in the brain, apoptosis appears to be the main mode of cell death induced by NNs. Apoptosis can be triggered by two main pathways: the extrinsic (or death receptor) pathway and the intrinsic (or mitochondrial) pathway. The extrinsic pathway is triggered outside the cell by death ligands, which bind to and activate death receptors located on the cell membrane [195]. Activation of these receptors leads to activation of caspase-8, which cleaves other downstream caspases and ultimately causes cell death [196]. In line with this, it has been shown that exposure to NN pesticides enhanced the expression of TNF- $\alpha$, which can act as a death ligand and trigger the extrinsic pathway of apoptosis [128].

The intrinsic or mitochondrial pathway of apoptosis is usually triggered inside the cell in response to noxious stimuli, such as excessive increases in intracellular ROS and $\mathrm{Ca}^{+2}$ concentrations [197]. These cellular stress factors trigger the activation of the Bax protein to form pores in the outer mitochondrial membrane and release cytochrome $C$, which triggers the activation of caspases in the cytosol and apoptosis [198]. As previously mentioned, treatment with $\mathrm{NN}$ compounds induced an increase in intracellular $\mathrm{Ca}^{+2}$ concentration and increased oxidative stress, two conditions closely related to the activation of the mitochondrial pathway of apoptosis $[120,128,155,156]$.

Some of the research has shown that ACE pesticide exposure caused neuronal death through apoptosis $[60,155]$. Likewise, the team of Abd-Elhakim et al. [70] observed that exposure to IMI increased the levels of the pro-apoptotic protein Bax, while reducing the concentration of the anti-apoptotic protein Bcl-2, which under physiological conditions, keep apoptosis-inducing proteins, such as Bax inactive [199]. These results suggest that, possibly due to adverse conditions caused by NN pesticides in the brain, both the intrinsic and extrinsic pathways of cellular apoptosis may be activated.

\subsection{Effect of NNs on Humans}

Available studies on the effects of NN pesticides on humans are limited and only seven studies in total have been identified. The results are summarized in Tables 3 and 4 .

\subsubsection{In Vitro Neurotoxic Effects on Human Cell Cultures}

A total of three in vitro studies have been identified evaluating the effects of exposure of the human neuroblastoma cell line SH-SY5Y to the pesticides IMI, ACE, CLO, THI and/or TMX over a 24- or 48-h period.

In the study by Hirano et al. [200] different concentrations of CLO $(1-100 \mu \mathrm{M})$ were administered to SH-SY5Y cells expressing $\alpha 3, \alpha 7, \beta 2$ and $\beta 4$ nAChRs subunits. The pesticide caused a dose-dependent increase in the number of cells and the growth of their neurites. According to the authors, this effect was due to the agonist action of CLO on $n A C h R s$, indicating that the pesticide was able to activate these receptors and increase $\mathrm{Ca}^{+2}$ 
entry into the cell interior. This increase in intracellular $\mathrm{Ca}^{+2}$ levels could be responsible for the ERK activation caused by the pesticide [201]. ERKs are important components of signaling cascades that regulate a variety of cellular activities in the CNS, including cell proliferation, migration and differentiation [202]. In line with this, some of the metabolites of NNs have been shown to have a higher affinity for human nAChRs and can induce higher ERK activation than the parent compound [203]. Thus, further studies investigating the potential effects of the metabolites of these NN pesticides should also be conducted.

Another finding documented in the study by Hirano et al. [200] was that CLO exposure downregulated several genes related to neuronal function and morphology. These changes could underlie the increase in neurite length that was observed during neuronal differentiation. In contrast, in the study by Cheng et al. [204] administration of higher concentrations (10-2000 mg/L) of IMI, ACE and TMX caused significant inhibition of cell growth and viability. Similarly, in the research of Şenyildiz et al. [205] the exposure to IMI, ACE, CLO, THI and TMX (0.05-4 mM) induced neuronal DNA damage, especially at the higher concentrations. Furthermore, the results of both studies show that THI and TMX are significantly more toxic than the other NNs used in the studies.

Taken together, the results of the in vitro studies suggest that, although excessive amounts of NNs can cause cell death, exposure to low concentrations could have proliferative effects. As has been observed for other mechanisms of neurotoxicity discussed in the present review, the results of the in vitro studies described here are consistent with those described for nicotine under similar experimental conditions [206,207].

\subsubsection{Descriptive and Analytical Studies}

The neurotoxic effects that NN pesticides can produce in the nervous system depend on their ability to cross the BBB. The team of Vinod et al. [208] described the case of a 23-year-old man who deliberately ingested THI mixed with alcohol. The intoxication manifested with a wide range of symptoms, including status epilepticus and profound unconsciousness, suggesting the ability of NNs to cross the human BBB.

Similarly, in the study by Marfo et al. [209], a relationship was found between environmental exposure of the general population to ACE and TMX pesticides and the appearance of a symptom picture called "neonicotinic symptoms". This set of symptoms was characterized by loss of recent memory, headache, generalized fatigue, tremor of the fingers or muscle weakness, among others. Some of these symptoms could reflect, again, the ability of NN molecules to penetrate the CNS by crossing the BBB. Other neurological symptoms such as disorientation, fever, dizziness or drowsiness were also reported in studies of people intoxicated with IMI [210-212].

On the other hand, some studies have suggested that exposure to NN pesticides during pregnancy may be related to an increased risk of developing autism spectrum disorders (ASD) and a lower IQ of the offspring, although these results should be interpreted with caution $[213,214]$. In this regard, several studies provided evidence of a possible association between neurodevelopmental disorders and exposure to environmental chemicals such as pesticides, especially during the gestational period $[215,216]$. For it has been shown that fetuses, infants and children are especially vulnerable to exposure to toxic chemicals in the environment $[217,218]$.

\subsection{Effects of NNs on Other Mammals}

Only three studies have described the role of NNs on mammals other than rodent and humans. Specifically, one of the investigations focuses on the toxic effects of IMI on adult female white-tailed deer (Odocoileus virginianus) and their offspring, while the remaining two studies evaluate the impact of this pesticide on the great roundleaf bat (Hipposiderosa armiger terasensis). A summary of the results described in these articles is shown in Table 5. 
Table 3. Effects of neonicotinoid pesticides in human cells observed in vitro.

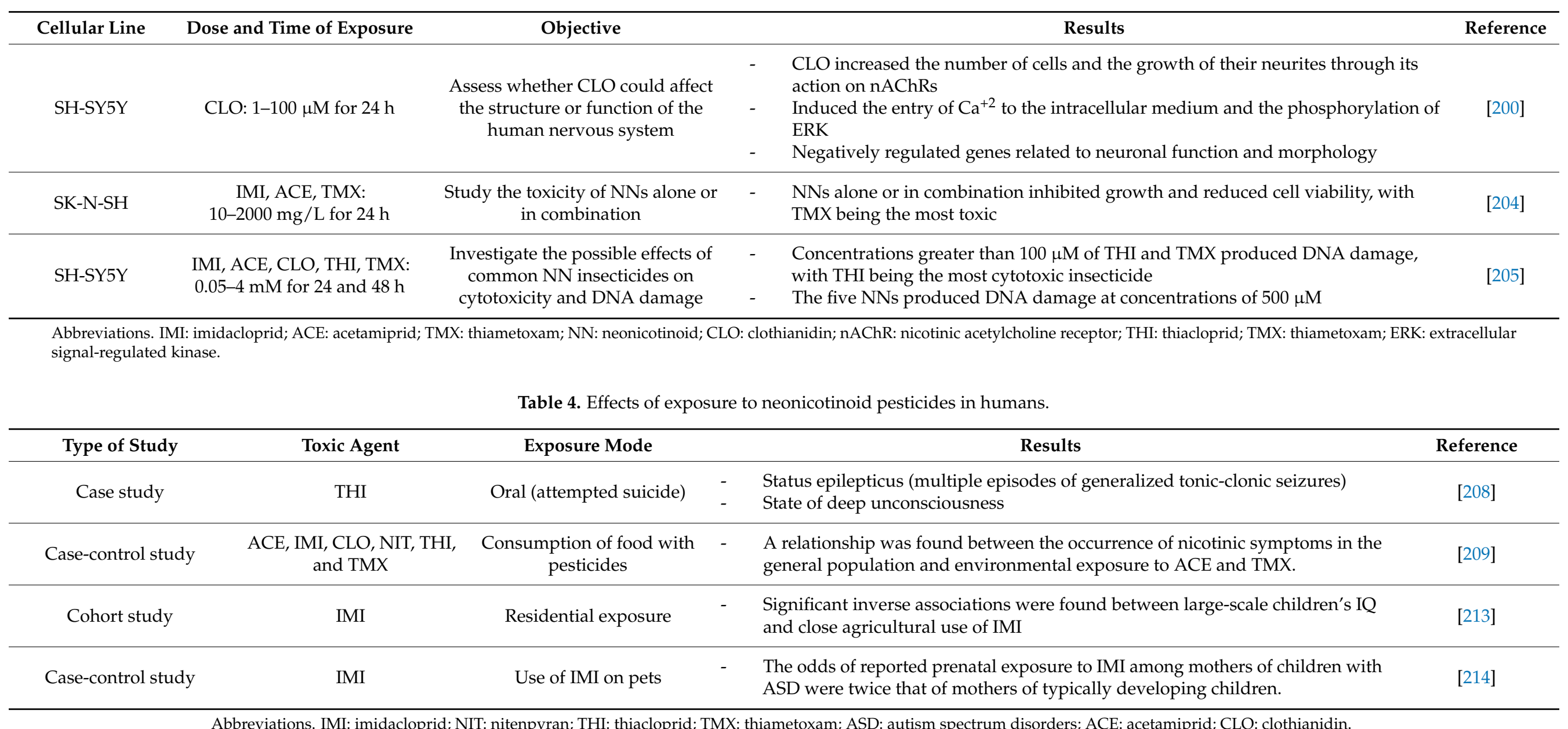


Table 5. Neurotoxic effects of neonicotinoid pesticides in other mammalian species.

\begin{tabular}{|c|c|c|c|c|}
\hline Species & Dose and Time Exposition & Objectives & Results & Reference \\
\hline $\begin{array}{c}\text { Deer } \\
\text { (Odocoileus virginianus) }\end{array}$ & $\begin{array}{l}\text { IMI: } 1.500,3.000 \text { or } 15.000 \mathrm{ng} / \mathrm{L} \text { orally } \\
\text { From May to October }\end{array}$ & $\begin{array}{l}\text { Assess the toxic effects of IMI in } \\
\text { adult female white-tailed deer }\end{array}$ & $\begin{array}{l}\text { - IMI was present in the organs of the control group animals } \\
\text { - IMI values in the brain were low or undocumented }\end{array}$ & [219] \\
\hline $\begin{array}{c}\text { Bat } \\
\text { (Hipposiderosarmiger terasensis) }\end{array}$ & IMI: $20 \mathrm{mg} / \mathrm{kg}$ orally for 5 days & $\begin{array}{l}\text { Compare spatial memory of bats } \\
\text { before and after chronic } \\
\text { treatment with a low dose of IMI }\end{array}$ & $\begin{array}{l}\text { - The stereotypical flight patterns of the treated bats were } \\
\text { different from their originally learned paths } \\
\text { - Increased Bax/Bcl-2 ratio and levels of caspase } 3 \text { and } \\
\text { caspase } 3 \text { cleaved in the CA1 hippocampus and areas of the } \\
\text { medial entorhinal cortex }\end{array}$ & [111] \\
\hline $\begin{array}{c}\text { Bat } \\
\text { (Hipposideros armiger terasensis) }\end{array}$ & IMI: $0.5 \mathrm{mg}$ orally for 5 days & $\begin{array}{l}\text { Examine whether IMI toxicity } \\
\text { can interfere with the } \\
\text { echolocation system of bats }\end{array}$ & $\begin{array}{l}\text { - } \quad \text { The bats were disoriented after treatment } \\
\text { - } \quad \text { Decreased expression of FOXP2, prestin and otoferlin } \\
\text { proteins } \\
\text { - } \quad \text { Increased expression of TNF- } \alpha \\
\text { - } \quad \text { Increased expression of cytochrome C and caspases } 3 \text { and } 12\end{array}$ & [220] \\
\hline
\end{tabular}

Abbreviations. IMI: imidacloprid; FOXP2: Forkhead box protein P2; TNF- $\alpha$ : tumor necrosis factor alpha. 
In the study by Berheim et al. [219] the presence of the pesticide IMI was detected in the body of all deer, both in those treated with the pesticide and in the control group. These results indicate the presence of NNs in the environment, mainly in food and vegetation. In addition, although IMI was detected in many of the organs of white-tailed deer, the values detected in the brain were low or undocumented. These findings were attributed to the inability of the pesticide to cross the BBB in these animals.

Research by Hsiao et al. [111] and Wu et al. [220] evaluated the impact of chronic IMI treatment on the echolocation system of bats. Echolocation is an orientation system used by some animals by which they gather information from the environment by making use of echoes [221]. This system allows bats to orient themselves through complex environments and to locate and identify objects in complete darkness [222,223]. It has been shown that, after exposure to IMI insecticide, bats were disoriented and showed irregular flight paths $[111,220]$.

In addition, exposure of bats to IMI was associated with a marked increase in neural apoptosis in the hippocampal CA1 area and the medial entorhinal cortex [111,220]. As previously commented, this apoptotic pathway is initiated by an increase in the permeability of the mitochondrial outer membrane and the release of various proteins, such as cytochrome C, into the cytoplasm [224]. Consequently, effector caspases, such as caspase 3 , are activated by cleavage events and collectively orchestrate the execution of apoptosis [225]. In this regard, the team of Wu et al. [220] documented the enhanced expression of apoptotic cytochrome $\mathrm{C}$ and caspase 3 molecules in bat cerebral cortex tissue.

On the other hand, stress conditions that interfere with endoplasmic reticulum (ER) homeostasis can also initiate a process of apoptosis different from the one previously discussed [226]. During ER stress-mediated apoptosis, caspase 12 translocate from the ER to the cytosol, where it cleaves and activates pro-caspase 9, which, in turn, activates caspase 3 or effector caspase [227]. Thus, it has been shown that exposure to IMI increased the expression levels of caspase 12 and caspase 3 in bat cochlear tissue [220].

In addition, the team of $\mathrm{Wu}$ et al. [220] also detected an increase in TNF- $\alpha$ expression in both cortical and cochlear tissue of bats. TNF- $\alpha$ is an apoptosis-inducing death ligand, so the increase in its levels may be directly related to activation of the extrinsic pathway of apoptosis and, alternatively, may also induce activation of the intrinsic or mitochondrial pathway of apoptosis [228].

Taken together, these data suggest that one of the mechanisms by which IMI could alter the echolocation system of bats is through cell death in brain areas involved in spatial memory processing. Specifically, it appears that IMI-induced apoptosis may occur through mitochondrial dysfunction in the cerebral cortex and ER stress in the cochlea.

In the research of Wu et al. [220], IMI administration to bats also reduced the expression of brain proteins related to echolocation. On the one hand, otoferlin is a protein expressed by sensory hair cells that plays a crucial role in auditory function and is expressed in the brain and inner ear $[229,230]$. This protein plays an important role in the transmission of sound signals in the brain during echolocation [231]. It has been shown that IMI exposure decreased the expression of the hearing-related orthophelin in the cochlea and inferior colliculus [220].

$\mathrm{Wu}$ et al. [220] also found that the pesticide reduced the expression of prestin, a cochlear protein related to hearing. Prestin is a membrane motor protein localized to outer hair cells that is essential for cochlear amplification and is widely expressed in echolocating animals [232-234]. Similarly, exposure to IMI downregulated the expression of Forkhead box protein P2 (FOXP2), a voice-related protein in the superior colliculus [220]. FOXP2 is a transcription factor involved in the coordination of orofacial movements required for speech and whose alteration is associated with language disorders [235]. Thus, it is considered that FOXP2 may be involved in the neural circuits that support echolocation in bats $[236,237]$. 
Therefore, the set of results suggests that IMI treatment interferes with the orientation system and the spatial, auditory and vocal memory of bats, which are essential for the correct functioning of their echolocation ability.

\subsection{Discussion}

Most of the studies analyzed were conducted in rodents and provided valuable information on the biochemical mechanisms by which NN pesticides produce toxicity in the mammalian nervous system. First, sufficient evidence has been collected on the ability of these insecticides to cross the $\mathrm{BBB}$ and reach the CNS, as evidenced by the presence of NNs in the brain tissue of rodents or the neurological symptoms observed in humans. Once in the brain, the NNs produce important neurotoxic effects, which appear to vary depending on the vital moment in which the exposure occurs.

The results show that many of the neurotoxic effects observed after exposure to NN pesticides are directly or indirectly related to their action on $\mathrm{nAChR}$ receptors. Although NNs have low affinity for these receptors, the great variety and ubiquity of nAChRs, present from protozoa to higher eurokaryotes, adds to their diversity of functions, such as the regulation of neuronal development, the modulation of various neurotransmission systems, the learning, memory, and emotions, increases the risk of NNs toxicity in the nervous system.

The nAChRs are widely distributed throughout the mammalian CNS, but especially in areas such as the cortex, striatum, hippocampus, thalamus, hypothalamus, amygdala, ventral tegmental area, cerebellum or some nuclei of the brain stem $[238,239]$. Some of the studies included in the present review demonstrated that the most commonly expressed subtypes are the heteromeric $\alpha 4 \beta 2$ type and the homomeric $\alpha 7$ type receptors [240], being these receptors responsible for the effects of NNs in the mammalian nervous system. Figure 3 summarizes the main neurotoxic effects induced by the NNs described in the studies analyzed in this review.

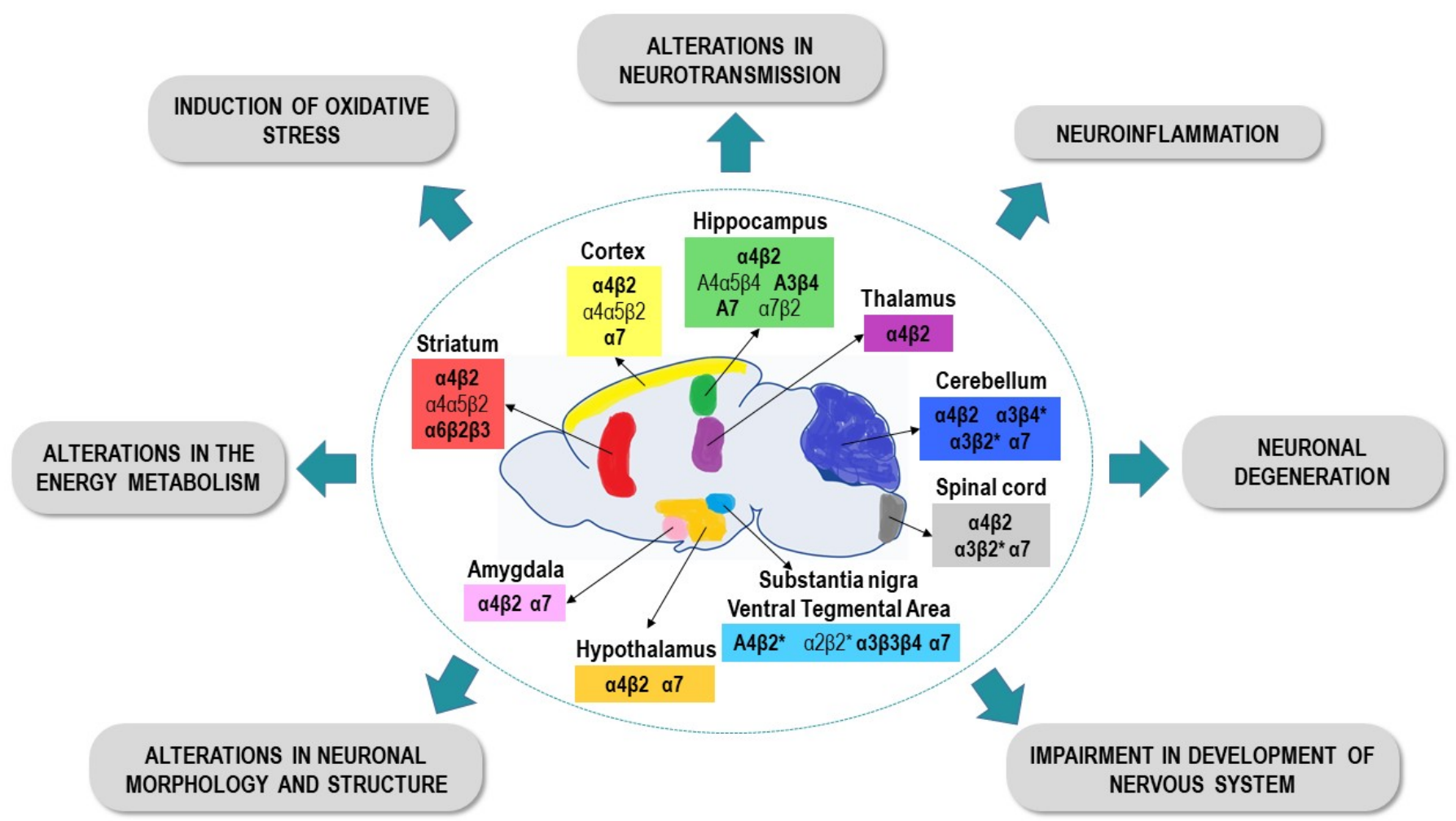

Figure 3. Distribution of the nAChR subtypes identified in some regions of the rodent CNS, and the main toxic effects observed after exposure to NNs pesticides in the rodent CNS. 
Anatomical and functional evidence suggests that the $\alpha 4 \beta 2$ and $\alpha 7$ type receptors are both pre- and postsynaptic and their activation promotes the entry of $\mathrm{Ca}^{+2}$ into the neuronal interior. In this way, the activation of these receptors and the influx of $\mathrm{Ca}^{+2}$ into the neuron can modulate the release of almost all neurotransmitters, both excitatory and inhibitory [238]. This could explain, at least partially, the alterations in the different neurotransmission systems observed after exposure to NN pesticides.

It has been shown that, after a short exposure to nicotine, the $\alpha 4 \beta 2$ receptors becomes desensitized, whereas $\alpha 7$, being less sensitive, remains functional even when exposed to very high concentrations of this agonist [241]. The $\alpha 7$ receptors allow the $\mathrm{Na}^{+}$entry and are highly permeable to $\mathrm{Ca}^{+2}$, while the $\alpha 4 \beta 2$ receptors, although they allow the $\mathrm{Na}^{+}$entry through them, have a lower permeability to $\mathrm{Ca}^{+2}$ [242]. On the other hand, most studies evaluate the effects of NNs administered chronically in periods ranging from 2 to 24 weeks of exposure. Thus, prolonged exposure may induce changes in the two receptor subtypes in a similar way to nicotine, desensitizing and closing the $\alpha 4 \beta 2$ receptors, while the $\alpha 7$ receptors remain active.

Some of the studies analyzed in this review show that one of the main effects produced by NNs is the increase in the influx of $\mathrm{Ca}^{+2}$ in both rodent neurons and human cells in vitro. $\mathrm{Ca}^{+2}$ is a general intracellular messenger and controls virtually all aspects of neuronal function (e.g., metabolism, synaptic transmission and plasticity, gene transcription, programmed cell death) [121], and cells possess mechanisms responsible for maintaining its intracellular concentrations at sufficiently low levels [243]. Therefore, the increase in the $\mathrm{Ca}^{+2}$ levels in the cytosol can trigger multiple biochemical effects in the cell, as show in Figure 4.

Furthermore, the NNs-induced nAChRs activation, mainly of $\alpha 7$ subtype, in addition to increasing $\mathrm{Ca}^{+2}$ entry, also increases $\mathrm{Na}^{+}$influx, which depolarizes the neuronal membrane and opens voltage-gated ion channels, including the voltage-dependent calcium channels (VDCC), increasing even more the intracellular $\mathrm{Ca}^{+2}$ concentrations. This $\mathrm{Ca}^{+2}$ of extracellular origin can bind to ryanodine receptors, which are $\mathrm{Ca}^{+2}$ channels present in the ER membrane, causing their opening and the release of $\mathrm{Ca}^{+2}$, further increasing its level in the cytosol [243]. On the other hand, an increase in the $\mathrm{Ca}^{+2}$ levels and its binding to calmodulin can activate the eNOS and nNOS, which contribute to oxidative stress, as observed in several of the studies analyzed. The excessive $\mathrm{Ca}^{+2}$ levels can also promote the activation of calcium-binding calpain proteases, which can lead to the degradation of proteins and structural enzymes [126,244].

Exposure to NN pesticides can also alter the functioning of mitochondria, organelles closely related to maintaining calcium homeostasis. On the one hand, under conditions of oxidative stress, excess ROS causes damage and induces depolarization of the mitochondrial membrane, which impairs the ability of these organelles to maintain $\mathrm{Ca}^{+2}$ inside and can cause its release to the cytosol [243]. On the other hand, the sustained opening of certain nAChRs and the excessive accumulation of $\mathrm{Ca}^{+2}$ can cause an increase in its levels in the mitochondria, which, in turn, can cause mitochondrial inflammation and the release of apoptotic factors to the cytosol [245].

In this way, the pathological conditions induced by exposure to $\mathrm{NN}$ compounds, such as dysregulation of $\mathrm{Ca}^{+2}$ homeostasis, oxidative stress, inflammation or mitochondrial dysfunction, could eventually lead to the death of neurons in the CNS (Figure 3). However, it appears that not all brain regions are equally vulnerable to $\mathrm{NN}$-induced damage. Previous studies have shown that different types of neurons exhibit different sensitivities to $\mathrm{Ca}^{+2}$ dysregulation, with the hippocampal and cortical neurons presenting the greatest vulnerability [243]. These findings are consistent with the results analyzed here, since several studies have shown that exposure to NNs produced important structural and functional alterations in the hippocampus. These results suggest that the hippocampus could be especially vulnerable to exposure to NN pesticides, which is likely related to the number and types of $\mathrm{nAChRs}$ found in this region. 


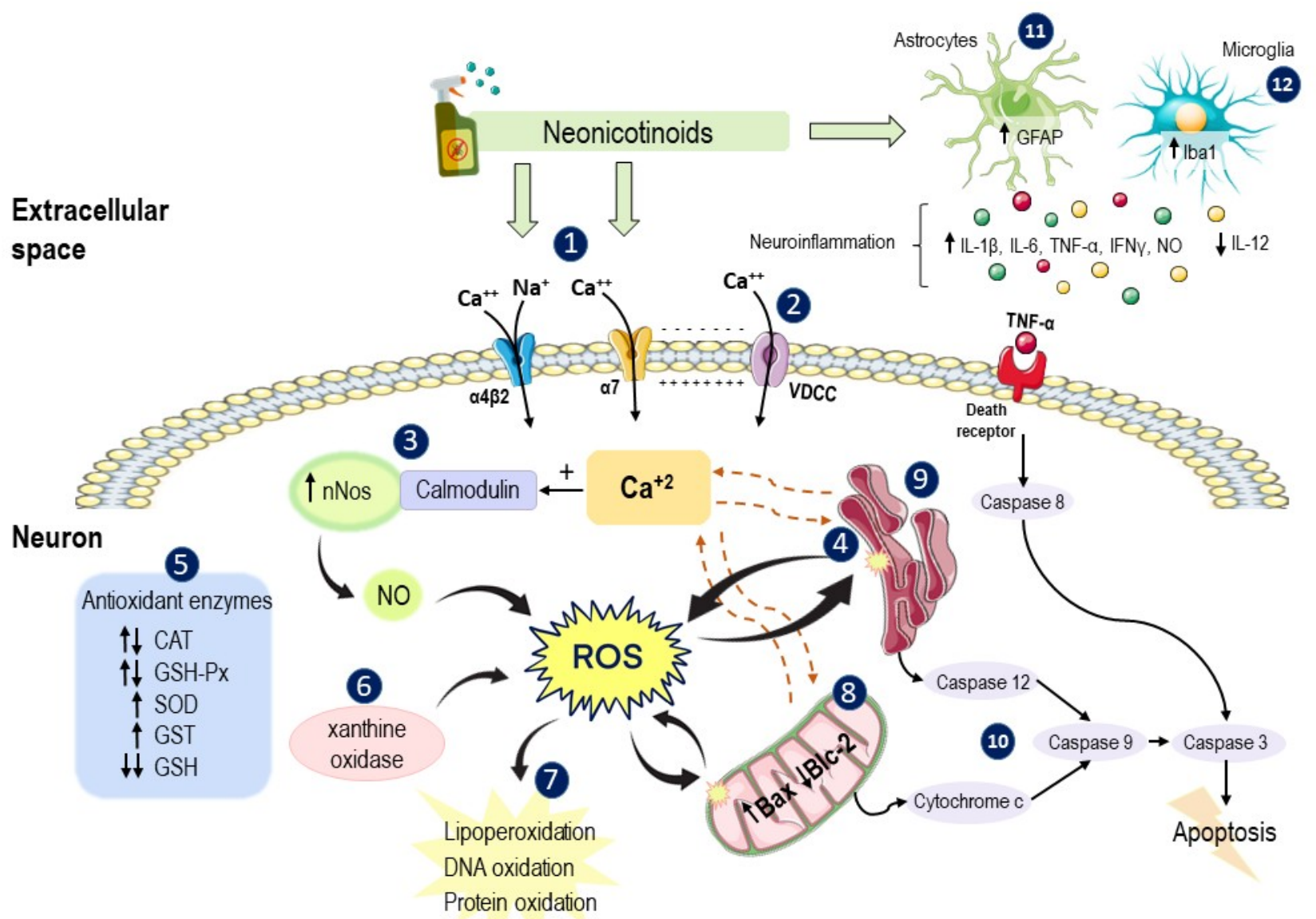

Figure 4. Main mechanisms of neurotoxicity proposed for NN pesticides in the nervous system of rodents, human, and other mammals. NNs induce activation of $\alpha 4 \beta 2$ and $\alpha 7$ subtype receptors (1), increased $\mathrm{Ca}^{+2}$ influx, membrane depolarization, and VDCC opening (2), with a greater increase in $\mathrm{Ca}^{+2}$ levels. $\mathrm{Ca}^{+2}$ can bind to calmodulin, increasing NO synthesis (3) and ROS production, and it can also bind to ER ryanodine receptors (4), further increasing its concentrations in the cytosol. NNs also modify the activity of several antioxidant enzymes (5) and increase the activity of xanthine oxidase (6) and, consequently, there is an increase in ROS production. Increased levels of ROS lead to LPO, DNA and protein oxidation (7), and severely affect mitochondria (8) and ER (9), activating two different pathways of cellular apoptosis (10). NNs also induce astrocyte and microglial activation, with upregulation of GFAP (11) and Iba1 (12), respectively, and increased release of pro-inflammatory cytokines and ROS. Some of these molecules, such as TNF- $\alpha$, can bind to death receptors and trigger neuronal apoptosis (13). Parts of the figure were created using templates from Servier Medical Art, which are licensed under a Creative Commons Attribution 3.0 Unported License (http:/ / smart.servier.com/ accessed on: 6 July 2021). Abbreviations: VDCC: voltage-dependent calcium channels; nNOS: neuronal nitric oxide synthase; NO: nitric oxide; ROS: reactive oxygen species; CAT: catalase; GSH-Px: glutathione peroxidase; SOD: superoxide dismutase; GST: Glutathione S-transferase; GSH: glutathione; GFAP: glial fibrillary acidic protein; IL-12: interleukin 12; IL-1 $\beta$ : interleukin 1beta; IL-6: interleukin 6; TNF- $\alpha$ : tumor necrosis factor alpha.

The broad range of effects induced by exposure to NN pesticides, such as the alteration of neurotransmission systems, can ultimately lead to the manifestation of behavioral and cognitive changes. Thus, the results described suggest that this class of insecticides could cause significant alterations in sensorimotor functions, mood, anxiety or social behavior, as well as cause deficits in orientation, learning and memory processes.

On the other hand, when exposure takes place during the prenatal or early postnatal period, the NNs can deregulate the expression of genes essential for proper neuronal development, resulting in the manifestation of alterations in the number or morphology of these cells. These disturbances derived from early exposure could favor the appearance of developmental disorders of the nervous system or deficits in intellectual capacity. 
The results obtained in bats are also of special relevance, since it has been shown that exposure to NNs can seriously affect their echolocation system, which plays a fundamental role in navigation and search for food. Thus, environmental contamination with NN pesticides could have serious repercussions for the survival of these mammals.

The findings collected here show that the effects produced by NN pesticides are not limited to their action on insect $\mathrm{nAChRs}$ but are also derived from their interaction with mammalian nAChRs, generating important neurotoxic effects on the nervous system of the different species studied, including humans. However, there are few published studies to date, showing the need for more research to clarify the biochemical and molecular mechanisms by which these pesticides alter the function and structure of the nervous system. This is especially relevant in cases of prolonged exposures to low concentrations of NNs, which are the conditions to which a large part of the general population is exposed, and which can pose a serious risk to their health.

\section{Relevance of Daily Human Exposure to Pesticides NNs}

To finalize this review, it is necessary to refer to the possible implications that exposure to the actual amounts of NNs present in the environment may have on human health. In recent years, environmental concentrations of NNs ranging from $0.001-320 \mu \mathrm{g} / \mathrm{L}$ have been detected in surface runoff from soils, streams and groundwater [246,247]. In addition, various studies have demonstrated the persistence of these pesticides in agricultural soils, where they can reach half-lives that vary between 9-1250 days for IMI, 6-3001 days for TMX and 17-6931 days for CLO [248]. Therefore, the increasing use of products containing NNs and their repeated application to crops has been linked to increasing levels of residues in the soil, which are indicative of environmental accumulation of pesticides throughout of the years [247].

In addition, the presence of NNs and their metabolites has been detected in numerous varieties of fruits and vegetables commonly consumed, as well as in drinking water and bovine milk $[17,249]$. Therefore, the general population is continually exposed to these pesticides. This has been confirmed in several studies in which the presence of these compounds and their metabolites was detected in the hair and urine of the general population [250]. While the concentrations of NNs to which humans are exposed have not been fully established, some studies have reported concentrations in human urine ranging from $0.03-2.27 \mu \mathrm{g} / \mathrm{L}$ of NNs and/or their metabolites [42,249].

However, it has been observed that the mean concentrations of NNs in urine have maintained a constant growth during the last years, reflecting an increasingly widespread use [249]. This can pose a serious risk, since the bioaccumulation of these compounds could occur in humans because of the consecutive ingestion of food and water contaminated with NNs. Although information on the bioaccumulation of NNs in humans is extremely limited, several animal studies have shown the ability of these pesticides to accumulate in a dose-dependent manner in the body after chronic exposure [60,251].

It appears that current environmental concentrations of NNs are relatively low and may not pose a health risk to adult humans. However, they could pose a risk to fetuses, as human and rodent studies have shown that both NNs and their metabolites can be transferred rapidly through the placenta and accumulate in the fetus [57,250,252]. Since during brain development the BBB of fetuses and neonates is immature, this will facilitate the penetration and accumulation of different chemicals, such as pesticides, in their brain [253].

On the other hand, it has been shown that some of the metabolites of NNs could persist for a longer time in the brain of mammals, mainly in the elderly. These compounds accumulate in lipid-rich tissue, such as brain tissue, and some of their metabolites have a higher affinity for mammalian nAChRs compared to the parent compound [254]. Therefore, the chronic exposure to which most humans are subjected could lead to the accumulation of these pesticides in the brain and increase the risk of neurological disorders. This could especially affect the elderly, due to their greater difficulty in metabolizing and eliminating 
these compounds. Thus, children and the elderly appear to be particularly susceptible to the toxicity of NNs pesticides, so the use of these compounds could be a public concern.

An important aspect that should be reconsidered is the current configuration of acceptable levels of NNs, which vary greatly from one country to another. For example, while in the European Union the maximum limit for IMI residues in tea is $0.05 \mathrm{mg} / \mathrm{kg}$, in China this limit is ten times higher, specifically, $0.5 \mathrm{mg} / \mathrm{kg}$ [249]. Considering these values, it is evident that most of the research analyzed in this review used higher doses to study the mechanisms of toxicity of pesticides. However, in the study by Burke et al. [57] a dose of $0.5 \mathrm{mg} / \mathrm{kg}$ of IMI was administered to mice from pregnancy and pesticide was detected in the brains of mothers and offspring. This dose of pesticide was related to the appearance of alterations in the behavior and mood of the offspring. Similarly, the same dose of IMI also produced behavioral alterations in the study by Khalil et al. [71]. These results show that the consumption of NNs in amounts that are within the legal limits allowed in some countries could pose a significant risk to health. Therefore, future studies should attempt to determine the lowest dose of each $\mathrm{NN}$ pesticide subtype that is capable of inducing biochemical and behavioral abnormalities, as well as concomitantly quantifying tissue levels and their excretion in urine.

In short, NNs were traditionally considered to have less toxicity in mammals due to their poor penetration through the BBB and their lower affinity for mammalian nAChRs. This assumption has been widely accepted and has led to an increasing use of this class of pesticides in modern agriculture. However, the results analyzed in the present review contradict this notion and demonstrate that these compounds can cross the BBB and that some of their metabolites could have a higher affinity for mammalian nAChRs than the parent compound. Consequently, NNs pesticide residues could accumulate in the human brain and cause important neurological disorders, especially in infants and the elderly. For this reason, these findings suggest the need to introduce modifications in the accepted limits for NNs in some countries and adopt more conservative values. Above all, taking into account that fetuses are also exposed to pesticides and their metabolites at levels similar to those of the mother.

\section{Limitations}

The main limitation of the present systematic review is that most of the findings on the neurotoxic effects of NN pesticides in mammals have been obtained from studies in rodents. Therefore, various methodological aspects must be considered before extrapolating the results obtained using animal models to human problems. A central issue with generalizing results is found in the differences between species, doses of pesticides, exposure times, and in the routes of administration used. Regarding the routes of administration, studies have focused mainly on investigating the effects of oral administration of pesticides, a route of exposure that can be very useful to assess the effects of consuming food or water contaminated with NNs. However, other routes of exposure to NN pesticides have not been sufficiently investigated, such as the dermal route or the respiratory route.

On the other hand, although there are central elements and developmental patterns that are common for the different mammalian species, a clear equivalence between the periods of development of the rodent brain with the same periods in the human brain development has not been demonstrated [255]. For example, studies in which exposure to NN pesticides occurs during the early postnatal period of rodents, would correspond to the third trimester of gestation in humans [242]. Therefore, these considerations must be taken into account when generalizing the results described.

Finally, many of the studies included here show the effects derived from exposure to doses of NNs greater than those found in the environment or that the general population is routinely exposed. Therefore, exposure to lower doses of $\mathrm{NN}$ compounds may not cause the wide range of neurotoxic effects documented here, or at least not produce them with the same severity. 


\section{Conclusions}

The studies analyzed in this review indicate that exposure to NN pesticides can pose a risk to the integrity and functioning of the nervous system of different species of mammals, including humans. This neurotoxicity seems to originate from their action on nAChRs, especially the $\alpha 4 \beta 2$ and $\alpha 7$ subtypes, which are the most abundant in the CNS. Prolonged exposure to NNs can cause the sustained opening of some nAChRs, especially $\alpha 7$ subtype, which maintain their activity in the sustained presence of agonists and are highly permeable to $\mathrm{Ca}^{+2}$. Increased levels of $\mathrm{Ca}^{+2}$ can activate or inhibit a number of intracellular signaling pathways in both neurons and glial cells, leading to alterations in neurotransmission, oxidative stress or inflammation, which can further enhance neurotoxic conditions inside the cell. The activation of different apoptotic pathways ultimately leads to neuronal death.

The neurotoxic effects of $\mathrm{NN}$ pesticides appear to affect different brain regions differently, with the hippocampus being the most vulnerable. Thus, the damage caused by $\mathrm{NN}$ compounds is manifested in mammals with alterations in motor behavior, mood, anxiety, social behavior, as well as with serious deficiencies in the cognitive processes of orientation, learning and memory. These alterations can pose a clear risk to the survival of mammals and to human health, which is why future research needs to focus on knowing their true scope.

Author Contributions: C.C.-F. performed research and wrote the paper, critically revised and finalized the manuscript; L.R.F.F. designed study, wrote the paper, critically revised and finalized the manuscript. Both authors have read and agreed to the published version of the manuscript.

Funding: This research received no external funding.

Institutional Review Board Statement: Not applicable.

Informed Consent Statement: Not applicable.

Data Availability Statement: Not applicable.

Availability of Data and Material: Not applicable.

Conflicts of Interest: The authors declare no conflict of interest.

\section{Abbreviations}

ACE: acetamiprid; AChE: acetylcholinesterase; ASD: autism spectrum disorders; BBB: bloodbrain barrier; CAT: catalase; CD34: cluster of differentiation 34; CLO: clothianidin; CNS: central nervous system; CREB: cAMP response element-binding protein; DIN: dinotefuran; eNOS: endothelial nitric oxide synthase; ER: endoplasmic reticulum; ERK: extracellular signal-regulated kinase; FOXP2: forkhead box protein P2; GFAP: glial fibrillary acidic protein; GSH: glutathione; GSH-Px: glutathione peroxidase; GST: Glutathione $S$-transferase; IFN- $\gamma$ : interferon gamma; IL-12: interleukin 12; IL-1 $\beta$ : interleukin 1beta; IL-6: interleukin 6; IMI: imidacloprid; iNOS: inducible nitric oxide synthase; L-DOPA: L-3,4-dihydroxyphenylalanine; mAChR: muscarinic acetylcholine receptors; MDA: malondialdehyde; $n A C h R:$ nicotinic acetylcholine receptor; NMDA: N-methyl-D-aspartate; NN: neonicotinoid; nNOS: neuronal nitric oxide synthase; NO: nitric oxide; PKA: protein kinase A; PNMT: feniletanolamina N-metiltransferasa; ROS: reactive oxygen species; SOD: superoxide dismutase; TH: tyrosine hydroxylase; TNF- $\alpha$ : tumor necrosis factor alpha; VDCC: voltage-dependent calcium channels.

\section{References}

1. Jeschke, P.; Nauen, R.; Schindler, M.; Elbert, A. Overview of the status and global strategy for neonicotinoids. J. Agric. Food Chem. 2011, 59, 2897-2908. [CrossRef]

2. Bass, C.; Denholm, I.; Williamson, M.S.; Nauen, R. The global status of insect resistance to neonicotinoid insecticides. Pestic. Biochem. Physiol. 2015, 121, 78-87. [CrossRef]

3. Goulson, D. An overview of the environmental risks posed by neonicotinoid insecticides. J. Appl. Ecol. 2013, 50, 977-987. [CrossRef] 
4. Simon-Delso, N.; Amaral-Rogers, V.; Belzunces, L.P.; Bonmatin, J.M.; Chagnon, M.; Downs, C.; Furlan, L.; Gibbons, D.W.; Giorio, C.; Girolami, V.; et al. Systemic insecticides (neonicotinoids and fipronil): Trends, uses, mode of action and metabolites. Environ. Sci. Pollut. Res. Int. 2015, 22, 5-34. [CrossRef]

5. Tomizawa, M.; Casida, J.E. Selective toxicity of neonicotinoids attributable to specificity of insect and mammalian nicotinic receptors. Annu. Rev. Entomol. 2003, 48, 339-364. [CrossRef]

6. Jeschke, P.; Nauen, R. Neonicotinoids-from zero to hero in insecticide chemistry. Pest Manag. Sci. 2008, 64, 1084-1098. [CrossRef]

7. Yamamoto, I.; Tomizawa, M.; Saito, T.; Miyamoto, T.; Walcott, E.C.; Sumikawa, K. Structural factors contributing to insecticidal and selective actions of neonicotinoids. Arch. Insect Biochem. Physiol. 1998, 37, 24-32. [CrossRef]

8. Breer, H.; Sattelle, D.B. Molecular properties and functions of insect acetylcholine receptors. J. Insect Physiol. 1987, 33, 771-790. [CrossRef]

9. Dani, J.A. Neuronal nicotinic acetylcholine receptor structure and function and response to nicotine. Int. Rev. Neurobiol. 2015, 124, 3-19. [CrossRef] [PubMed]

10. Bartlett, A.J.; Hedges, A.M.; Intini, K.D.; Brown, L.R.; Maisonneuve, F.J.; Robinson, S.A.; Gillis, P.L.; de Solla, S.R. Lethal and sublethal toxicity of neonicotinoid and butenolide insecticides to the mayfly, Hexagenia spp. Environ. Pollut. 2018, 238, 63-75. [CrossRef] [PubMed]

11. Kara, M.; Yumrutas, O.; Demir, C.F.; Ozdemir, H.H.; Bozgeyik, I.; Coskun, S.; Eraslan, E.; Bal, R. Insecticide imidacloprid influences cognitive functions and alters learning performance and related gene expression in a rat model. Int. J. Exp. Pathol. 2015, 96, 332-337. [CrossRef]

12. Anderson, J.C.; Dubetz, C.; Palace, V.P. Neonicotinoids in the Canadian aquatic environment: A literature review on current use products with a focus on fate, exposure, and biological effects. Sci. Total Environ. 2015, 505, 409-422. [CrossRef] [PubMed]

13. Mohamed, F.; Gawarammana, I.; Robertson, T.A.; Roberts, M.S.; Palangasinghe, C.; Zawahir, S.; Jayamanne, S.; Kandasamy, J.; Eddleston, M.; Buckley, N.A.; et al. Acute human self-poisoning with imidacloprid compound: A neonicotinoid insecticide. PLoS ONE 2009, 4, e5127. [CrossRef]

14. Tomizawa, M.; Casida, J.E. Neonicotinoid insecticide toxicology: Mechanisms of selective action. Annu. Rev. Pharmacol. Toxicol. 2005, 45, 247-268. [CrossRef] [PubMed]

15. Katić, A.; Kašuba, V.; Kopjar, N.; Lovaković, B.T.; Marjanović Čermak, A.M.; Mendaš, G.; Micek, V.; Milić, M.; Pavičić, I.; Pizent, A.; et al. Effects of low-level imidacloprid oral exposure on cholinesterase activity, oxidative stress responses, and primary DNA damage in the blood and brain of male Wistar rats. Chem. Biol. Interact. 2021, 338, 109287. [CrossRef]

16. Bonmatin, J.M.; Giorio, C.; Girolami, V.; Goulson, D.; Kreutzweiser, D.P.; Krupke, C.; Liess, M.; Long, E.; Marzaro, M.; Mitchell, E.A.D.; et al. Environmental fate and exposure; neonicotinoids and fipronil. Environ. Sci. Pollut. Res. Int. 2015, $22,35-67$. [CrossRef] [PubMed]

17. Chen, M.; Tao, L.; McLean, J.; Lu, C. Quantitative analysis of neonicotinoid insecticide residues in foods: Implication for dietary exposures. J. Agric. Food Chem. 2014, 62, 6082-6090. [CrossRef] [PubMed]

18. Daraghmeh, A.; Shraim, A.; Abulhaj, S.; Sansour, R.; Ng, J.C. Imidacloprid residues in fruits, vegetables and water samples from Palestine. Environ. Geochem. Health 2007, 29, 45-50. [CrossRef] [PubMed]

19. Frenich, A.G.; Vidal, J.M.; Pastor-Montoro, E.; Romero-González, R. High-throughput determination of pesticide residues in food commodities by use of ultra-performance liquid chromatography-tandem mass spectrometry. Anal. Bioanal. Chem. 2008, 390, 947-959. [CrossRef] [PubMed]

20. Hladik, M.L.; Kolpin, D.W. First national-scale reconnaissance of neonicotinoid insecticides in streams across the USA. Environ. Chem. 2016, 13, 12-20. [CrossRef]

21. Iancu, V.; Petre, J.; Galaon, T.; Radu, G.L. Occurrence of neonicotinoid residues in Danube River and tributaries. Rev. Chim. 2019, 70, 313-318. [CrossRef]

22. Liu, S.; Zheng, Z.; Wei, F.; Ren, Y.; Gui, W.; Wu, H.; Zhu, G. Simultaneous determination of seven neonicotinoid pesticide residues in food by ultraperformance liquid chromatography tandem mass spectrometry. J. Agric. Food Chem. 2010, 58, 3271-3278. [CrossRef] [PubMed]

23. Niaz, A.; Sial, R.A.; Yaseen, M.; Mand, G.A.; Javed, M.H.; Ahmad, E.; Ahmad, R.; Rahim, M. Determination of imidacloprid residues in rice from various districts of Punjab using high performance liquid chromatography. J. Anim. Plant Sci. 2016, 26, 170-176.

24. Tanner, G.; Czerwenka, C. LC-MS/MS analysis of neonicotinoid insecticides in honey: Methodology and residue findings in Austrian honeys. J. Agric. Food Chem. 2011, 59, 12271-12277. [CrossRef] [PubMed]

25. Tišler, T.; Jemec, A.; Mozetič, B.; Trebše, P. Hazard identification of imidacloprid to aquatic environment. Chemosphere 2009, 76, 907-914. [CrossRef] [PubMed]

26. Xu, M.; Huang, H.; Li, N.; Li, F.; Wang, D.; Luo, Q. Occurrence and ecological risk of pharmaceuticals and personal care products (PPCPs) and pesticides in typical surface watersheds, China. Ecotoxicol. Environ. Saf. 2019, 175, 289-298. [CrossRef] [PubMed]

27. Tsvetkov, N.; Samson-Robert, O.; Sood, K.; Patel, H.S.; Malena, D.A.; Gajiwala, P.H.; Maciukiewicz, P.; Fournier, V.; Zayed, A. Chronic exposure to neonicotinoids reduces honey bee health near corn crops. Science 2017, 356, 1395-1397. [CrossRef] [PubMed]

28. Wood, T.J.; Goulson, D. The environmental risks of neonicotinoid pesticides: A review of the evidence post 2013. Environ. Sci. Pollut. Res. Int. 2017, 24, 17285-17325. [CrossRef] [PubMed] 
29. Woodcock, B.A.; Bullock, J.M.; Shore, R.F.; Heard, M.S.; Pereira, M.G.; Redhead, J.; Ridding, L.; Dean, H.; Sleep, D.; Henrys, P.; et al. Country-specific effects of neonicotinoid pesticides on honey bees and wild bees. Science 2017, 356, 1393-1395. [CrossRef]

30. Commission Implementing Regulation (EU) 2018/783 of 29 May 2018 Amending Implementing Regulation (EU) No 540/2011 as Regards the Conditions of Approval of the Active Substance Imidacloprid. 2018, Volume 132. Available online: https: / / eur-lex.europa.eu/legal-content/EN/TXT/?uri=CELEX:32018R0783 (accessed on 2 July 2021).

31. Badgujar, P.C.; Jain, S.K.; Singh, A.; Punia, J.S.; Gupta, R.P.; Chandratre, G.A. Immunotoxic effects of imidacloprid following 28 days of oral exposure in BALB/c mice. Environ. Toxicol. Pharmacol. 2013, 35, 408-418. [CrossRef]

32. Bagri, P.; Kumar, V.; Sikka, A.K. Assessment of imidacloprid-induced mutagenic effects in somatic cells of Swiss albino male mice. Drug Chem. Toxicol. 2016, 39, 412-417. [CrossRef]

33. Bal, R.; Naziroğlu, M.; Türk, G.; Yilmaz, Ö.; Kuloğlu, T.; Etem, E.; Baydas, G. Insecticide imidacloprid induces morphological and DNA damage through oxidative toxicity on the reproductive organs of developing male rats. Cell Biochem. Funct. 2012, 30, 492-499. [CrossRef] [PubMed]

34. Bhardwaj, S.; Srivastava, M.K.; Kapoor, U.; Srivastava, L.P. A 90 days oral toxicity of imidacloprid in female rats: Morphological, biochemical and histopathological evaluations. Food Chem. Toxicol. 2010, 48, 1185-1190. [CrossRef]

35. Duzguner, V.; Erdogan, S. Acute oxidant and inflammatory effects of imidacloprid on the mammalian central nervous system and liver in rats. Pestic. Biochem. Physiol. 2010, 97, 13-18. [CrossRef]

36. Gibbons, D.; Morrissey, C.; Mineau, P. A review of the direct and indirect effects of neonicotinoids and fipronil on vertebrate wildlife. Environ. Sci. Pollut. Res. Int. 2015, 22, 103-118. [CrossRef]

37. Kapoor, U.; Srivastava, M.K.; Srivastava, L.P. Toxicological impact of technical imidacloprid on ovarian morphology, hormones and antioxidant enzymes in female rats. Food Chem. Toxicol. 2011, 49, 3086-3089. [CrossRef] [PubMed]

38. Mikolić, A.; Karačonji, I.B. Imidacloprid as reproductive toxicant and endocrine disruptor: Investigations in laboratory animals. Arh. Hig. Rada. Toksikol. 2018, 69, 103-108. [CrossRef]

39. Rodrigues, K.J.A.; Santana, M.B.; Do Nascimento, J.L.M.; Picanco-Diniz, D.L.W.; Maues, L.A.L.; Santos, S.N.; Ferreira, V.M.M.; Alfonso, M.; Durán, R.; Faro, L.R.F. Behavioral and biochemical effects of neonicotinoid thiamethoxam on the cholinergic system in rats. Ecotoxicol. Environ. Saf. 2010, 73, 101-107. [CrossRef]

40. Abou-Donia, M.B.; Goldstein, L.B.; Bullman, S.; Tu, T.; Khan, W.A.; Dechkovskaia, A.M.; Abdel-Rahman, A.A. Imidacloprid induces neurobehavioral deficits and increases expression of glial fibrillary acidic protein in the motor cortex and hippocampus in offspring rats following in utero exposure. J. Toxicol. Environ. Health A 2008, 71, 119-130. [CrossRef] [PubMed]

41. Osaka, A.; Ueyama, J.; Kondo, T.; Nomura, H.; Sugiura, Y.; Saito, I.; Nakane, K.; Takaishi, A.; Ogi, H.; Wakusawa, S.; et al. Exposure characterization of three major insecticide lines in urine of young children in Japan-neonicotinoids, organophosphates, and pyrethroids. Environ. Res. 2016, 147, 89-96. [CrossRef]

42. Ospina, M.; Wong, L.Y.; Baker, S.E.; Serafim, A.B.; Morales-Agudelo, P.; Calafat, A.M. Exposure to neonicotinoid insecticides in the US general population: Data from the 2015-2016 national health and nutrition examination survey. Environ. Res. 2019, 176, 108555. [CrossRef]

43. Tao, Y.; Dong, F.; Xu, J.; Phung, D.; Liu, Q.; Li, R.; Liu, X.; Wu, X.; He, M.; Zheng, Y. Characteristics of neonicotinoid imidacloprid in urine following exposure of humans to orchards in China. Environ. Int. 2019, 132, 105079. [CrossRef]

44. Ueyama, J.; Harada, K.H.; Koizumi, A.; Sugiura, Y.; Kondo, T.; Saito, I.; Kamijima, M. Temporal levels of urinary neonicotinoid and dialkylphosphate concentrations in Japanese women between 1994 and 2011. Environ. Sci. Technol. 2015, 49, 14522-14528. [CrossRef]

45. Tomizawa, M.; Casida, J.E. Minor structural changes in nicotinoid insecticides confer differential subtype selectivity for mammalian nicotinic acetylcholine receptors. Br. J. Pharmacol. 1999, 127, 115-122. [CrossRef] [PubMed]

46. Cimino, A.M.; Boyles, A.L.; Thayer, K.A.; Perry, M.J. Effects of neonicotinoid pesticide exposure on human health: A systematic review. Environ. Health Perspect. 2017, 125, 155-162. [CrossRef]

47. Forrester, M.B. Neonicotinoid insecticide exposures reported to six poison centers in Texas. Hum. Exp. Toxicol. 2014, 33, 568-573. [CrossRef] [PubMed]

48. Imamura, T.; Yanagawa, Y.; Nishikawa, K.; Matsumoto, N.; Sakamoto, T. Two cases of acute poisoning with acetamiprid in humans. Clin. Toxicol. 2010, 48, 851-853. [CrossRef] [PubMed]

49. Phua, D.H.; Lin, C.C.; Wu, M.L.; Deng, J.F.; Yang, C.C. Neonicotinoid insecticides: An emerging cause of acute pesticide poisoning. Clin. Toxicol. 2009, 47, 336-341. [CrossRef]

50. Taira, K.; Aoyama, Y.; Kawakami, T.; Kamata, M.; Aoi, T. Detection of chloropyridinyl neonicotinoid insecticide metabolite 6-chloronicotinic acid in the urine: Six cases with subacute nicotinic symptoms. Chudoku Kenkyu 2011, $24,222-230$.

51. Todani, M.; Kaneko, T.; Hayashida, H.; Kaneda, K.; Tsuruta, R.; Kasaoka, S.; Maekawa, T. Acute poisoning with neonicotinoid insecticide acetamiprid. Chudoku Kenkyu 2008, 21, 387-390.

52. Iyyadurai, R.; George, I.A.; Peter, J.V. Imidacloprid poisoning-newer insecticide and fatal toxicity. J. Med. Toxicol. 2010, 6, 77-78. [CrossRef] [PubMed]

53. Proença, P.; Teixeira, H.; Castanheira, F.; Pinheiro, J.; Monsanto, P.V.; Marques, E.P.; Vieira, D.N. Two fatal intoxication cases with imidacloprid: LC/MS analysis. Forensic Sci. Int. 2005, 153, 75-80. [CrossRef] [PubMed]

54. Shadnia, S.; Moghaddam, H.H. Fatal intoxication with imidacloprid insecticide. Am. J. Emerg. Med. 2008, 26, 634.e1-634.e4. [CrossRef] [PubMed] 
55. Moher, D.; Liberati, A.; Tetzlaff, J.; Altman, D.G. The PRISMA Group. Preferred reporting items for systematic reviews and meta-analyses: The PRISMA statement. PLoS Med. 2009, 6, e1000097. [CrossRef]

56. Von Wedel-Parlow, M.; Wölte, P.; Galla, H.J. Regulation of major efflux transporters under inflammatory conditions at the blood-brain barrier in vitro. J. Neurochem. 2009, 111, 111-118. [CrossRef]

57. Burke, A.P.; Niibori, Y.; Terayama, H.; Ito, M.; Pidgeon, C.; Arsenault, J.; Camarero, P.R.; Cummins, C.L.; Mateo, R.; Sakabe, K.; et al. Mammalian susceptibility to a neonicotinoid insecticide after fetal and early postnatal exposure. Sci. Rep. 2018, 8, 1-13. [CrossRef]

58. Hirano, T.; Miyata, Y.; Kubo, S.; Ohno, S.; Onaru, K.; Maeda, M.; Kitauchi, S.; Nishi, M.; Tabuchi, Y.; Ikenaka, Y.; et al. Agingrelated changes in the sensitivity of behavioral effects of the neonicotinoid pesticide clothianidin in male mice. Toxicol. Lett. 2021, 342, 95-103. [CrossRef]

59. Kapoor, U.; Srivastava, M.K.; Trivedi, P.; Garg, V.; Srivastava, L.P. Disposition and acute toxicity of imidacloprid in female rats after single exposure. Food Chem. Toxicol. 2014, 68, 190-195. [CrossRef]

60. Shamsi, M.; Soodi, M.; Shahbazi, S.; Omidi, A. Effect of Acetamiprid on spatial memory and hippocampal glutamatergic system. Environ. Sci. Pollut. Res. Int. 2021, 28, 27933-27941. [CrossRef]

61. Terayama, H.; Endo, H.; Tsukamoto, H.; Matsumoto, K.; Umezu, M.; Kanazawa, T.; Ito, M.; Sato, T.; Naito, M.; Kawakami, S.; et al. Acetamiprid accumulates in different amounts in murine brain regions. Int. J. Environ. Res. Public Health 2016, 13, 937. [CrossRef]

62. Jin, X.; Wang, F.; Liu, X.; Liang, B.; Chen, Z.; He, J.; Zhang, H.; Zhang, J. Negative correlation of CD34 ${ }^{+}$cells with blood-brain barrier permeability following traumatic brain injury in a rat model. Microcirculation 2014, 21, 696-702. [CrossRef]

63. Christen, V.; Rusconi, M.; Crettaz, P.; Fent, K. Developmental neurotoxicity of different pesticides in PC-12 cells In Vitro. Toxicol. Appl. Pharmacol. 2017, 325, 25-36. [CrossRef]

64. Kimura-Kuroda, J.; Nishito, Y.; Yanagisawa, H.; Kuroda, Y.; Komuta, Y.; Kawano, H.; Hayashi, M. Neonicotinoid insecticides alter the gene expression profile of neuron-enriched cultures from neonatal rat cerebellum. Int. J. Environ. Res. Public Health 2016, 13, 987. [CrossRef]

65. Kagawa, N.; Nagao, T. Neurodevelopmental toxicity in the mouse neocortex following prenatal exposure to acetamiprid. J. Appl. Toxicol. 2018, 38, 1521-1528. [CrossRef]

66. Nakayama, A.; Yoshida, M.; Kagawa, N.; Nagao, T. The neonicotinoids acetamiprid and imidacloprid impair neurogenesis and alter the microglial profile in the hippocampal dentate gyrus of mouse neonates. J. Appl. Toxicol. 2019, 39, 877-887. [CrossRef] [PubMed]

67. Shideler, K.K.; Yan, J. M1 muscarinic receptor for the development of auditory cortical function. Mol. Brain 2010, 3, 29. [CrossRef] [PubMed]

68. Tanaka, T. Reproductive and neurobehavioral effects of clothianidin administered to mice in the diet. Birth Defects Res. B Dev. Reprod. Toxicol. 2012, 95, 151-159. [CrossRef] [PubMed]

69. Tanaka, T. Effects of maternal clothianidin exposure on behavioral development in F1 generation mice. Toxicol. Ind. Health 2012, 28, 697-707. [CrossRef] [PubMed]

70. Abd-Elhakim, Y.M.; Mohammed, H.H.; Mohamed, W.A. Imidacloprid impacts on neurobehavioral performance, oxidative stress, and apoptotic events in the brain of adolescent and adult rats. J. Agric. Food Chem. 2018, 66, 13513-13524. [CrossRef]

71. Khalil, S.R.; Awad, A.; Mohammed, H.H.; Nassan, M.A. Imidacloprid insecticide exposure induces stress and disrupts glucose homeostasis in male rats. Environ. Toxicol. Pharmacol. 2017, 55, 165-174. [CrossRef]

72. Drago, J.; McColl, C.D.; Horne, M.K.; Finkelstein, D.I.; Ross, S.A. Neuronal nicotinic receptors: Insights gained from gene knockout an knocking mutant mice. Cell. Mol. Life Sci. 2003, 60, 1267-1280. [CrossRef]

73. McGranahan, T.M.; Patzlaff, N.E.; Grady, S.R.; Heinemann, S.F.; Booker, T.K. $\alpha 4 \beta 2$ nicotinic acetylcholine receptors on dopaminergic neurons mediate nicotine reward and anxiety relief. J. Neurosci. 2011, 31, 10891-10902. [CrossRef]

74. Yoneda, N.; Takada, T.; Hirano, T.; Yanai, S.; Yamamoto, A.; Mantani, Y.; Yokoyama, T.; Kitagawa, H.; Tabuchi, Y.; Hoshi, N. Peripubertal exposure to the neonicotinoid pesticide dinotefuran affects dopaminergic neurons and causes hyperactivity in male mice. J. Vet. Med. Sci. 2018, 80, 634-637. [CrossRef]

75. Byrne, F.J.; Daugherty, M.P.; Grafton-Cardwell, E.E.; Bethke, J.A.; Morse, J.G. Evaluation of systemic neonicotinoid insecticides for the management of the Asian citrus psyllid Diaphorina citri on containerized citrus. Pest Manag. Sci. 2017, 73, 506-514. [CrossRef]

76. Kobashi, K.; Harada, T.; Adachi, Y.; Mori, M.; Ihara, M.; Hayasaka, D. Comparative ecotoxicity of imidacloprid and dinotefuran to aquatic insects in rice mesocosms. Ecotoxicol. Environ. Saf. 2017, 138, 122-129. [CrossRef]

77. Sánchez, C. Stress-induced vocalisation in adult animals. A valid model of anxiety? Eur. J. Pharmacol. 2003, 463, 133-143. [CrossRef]

78. Hirano, T.; Yanai, S.; Takada, T.; Yoneda, N.; Omotehara, T.; Kubota, N.; Minami, K.; Yamamoto, A.; Mantani, Y.; Yokoyama, T.; et al. NOAEL-dose of a neonicotinoid pesticide, clothianidin, acutely induce anxiety-related behavior with human-audible vocalizations in male mice in a novel environment. Toxicol. Lett. 2018, 282, 57-63. [CrossRef] [PubMed]

79. Brioni, J.D.; O'Neill, A.B.; Kim, D.J.; Decker, M.W. Nicotinic receptor agonists exhibit anxiolytic-like effects on the elevated plus-maze test. Eur. J. Pharmacol. 1993, 238, 1-8. [CrossRef]

80. Costall, B.; Kelly, M.E.; Naylor, R.J.; Onaivi, E.S. The actions of nicotine and cocaine in a mouse model of anxiety. Pharmacol. Biochem. Behav. 1989, 33, 197-203. [CrossRef] 
81. Gilbert, D.G.; Robinson, J.H.; Chamberlin, C.L.; Spielberger, C.D. Effects of smoking/nicotine on anxiety, heart rate, and lateralization of EEG during a stressful movie. Psychophysiology 1989, 26, 311-320. [CrossRef] [PubMed]

82. Pomerleau, O.F.; Turk, D.C.; Fertig, J.B. The effects of cigarette smoking on pain and anxiety. Addict. Behav. 1984, 9, $265-271$. [CrossRef]

83. Herbert, M.; Foulds, J.; Fife-Schaw, C. No effect of cigarette smoking on attention or mood in non-deprived smokers. Addiction 2001, 96, 1349-1356. [CrossRef]

84. Perkins, K.A.; Sexton, J.E.; Reynolds, W.A.; Grobe, J.E.; Fonte, C.; Stiller, R.L. Comparison of acute subjective and heart rate effects of nicotine intake via tobacco smoking versus nasal spray. Pharmacol. Biochem. Behav. 1994, 47, 295-299. [CrossRef]

85. Casarrubea, M.; Davies, C.; Faulisi, F.; Pierucci, M.; Colangeli, R.; Partridge, L.; Chambers, S.; Cassar, D.; Valentino, M.; Muscat, R.; et al. Acute nicotine induces anxiety and disrupts temporal pattern organization of rat exploratory behavior in hole-board: A potential role for the lateral habenula. Front. Cell. Neurosci. 2015, 9, 197. [CrossRef]

86. Foulds, J.; Stapleton, J.A.; Bell, N.; Swettenham, J.; Jarvis, M.J.; Russell, M.A. Mood and physiological effects of subcutaneous nicotine in smokers and never-smokers. Drug Alcohol Depend. 1997, 44, 105-115. [CrossRef]

87. Takada, T.; Yoneda, N.; Hirano, T.; Yanai, S.; Yamamoto, A.; Mantani, Y.; Yokoyama, T.; Kitagawa, H.; Tabuchi, Y.; Hoshi, N. Verification of the causal relationship between subchronic exposures to dinotefuran and depression-related phenotype in juvenile mice. J. Vet. Med. Sci. 2018, 80, 720-724. [CrossRef] [PubMed]

88. McClernon, F.J.; Hiott, F.B.; Westman, E.C.; Rose, J.E.; Levin, E.D. Transdermal nicotine attenuates depression symptoms in nonsmokers: A double-blind, placebo-controlled trial. Psychopharmacology 2006, 189, 125-133. [CrossRef] [PubMed]

89. Salín-Pascual, R.J.; Rosas, M.; Jimenez-Genchi, A.; Rivera-Meza, B.L. Antidepressant effect of transdermal nicotine patches in nonsmoking patients with major depression. J. Clin. Psychiatry 1996, 57, 387-389.

90. Semba, J.I.; Mataki, C.; Yamada, S.; Nankai, M.; Toru, M. Antidepressantlike effects of chronic nicotine on learned helplessness paradigm in rats. Biol. Psychiatry 1998, 43, 389-391. [CrossRef]

91. Janowsky, D.; Davis, J.; El-Yousef, M.K.; Sekerke, H.J. A cholinergic-adrenergic hypothesis of mania and depression. Lancet 1972, 300, 632-635. [CrossRef]

92. Fenster, C.P.; Rains, M.F.; Noerager, B.; Quick, M.W.; Lester, R.A. Influence of subunit composition on desensitization of neuronal acetylcholine receptors at low concentrations of nicotine. J. Neurosci. 1997, 17, 5747-5759. [CrossRef]

93. Fenster, C.P.; Whitworth, T.L.; Sheffield, E.B.; Quick, M.W.; Lester, R.A. Upregulation of surface $\alpha 4 \beta 2$ nicotinic receptors is initiated by receptor desensitization after chronic exposure to nicotine. J. Neurosci. 1999, 19, 4804-4814. [CrossRef] [PubMed]

94. Mineur, Y.S.; Picciotto, M.R. Biological basis for the co-morbidity between smoking and mood disorders. J. Dual Diagn. 2009, 5, 122-130. [CrossRef] [PubMed]

95. Paradiso, K.G.; Steinbach, J.H. Nicotine is highly effective at producing desensitization of rat $\alpha 4 \beta 2$ neuronal nicotinic receptors. J. Physiol. 2003, 553, 857-871. [CrossRef] [PubMed]

96. Quick, M.W.; Lester, R.A. Desensitization of neuronal nicotinic receptors. J. Neurobiol. 2002, 53, 457-478. [CrossRef]

97. Han, Z.Y.; Le Novère, N.; Zoli, M.; Hill Jr, J.A.; Champtiaux, N.; Changeux, J.P. Localization of nAChR subunit mRNAs in the brain of Macaca mulatta. Eur. J. Neurosci. 2000, 12, 3664-3674. [CrossRef] [PubMed]

98. Philip, N.S.; Carpenter, L.L.; Tyrka, A.R.; Price, L.H. Nicotinic acetylcholine receptors and depression: A review of the preclinical and clinical literature. Psychopharmacology 2010, 212, 1-12. [CrossRef] [PubMed]

99. Berntson, G.G.; Beattie, M.S.; Walker, J.M. Effects of nicotinic and muscarinic compounds on biting attack in the cat. Pharmacol. Biochem. Behav. 1976, 5, 235-239. [CrossRef]

100. Driscoll, P.; Baettig, K. Selective inhibition by nicotine of shock-induced fighting in the rat. Pharmacol. Biochem. Behav. 1981, 14, 175-179. [CrossRef]

101. Rodgers, R.J. Effect of nicotine, mecamylamine, and hexamethonium on shock-induced fighting, pain reactivity, and locomotor behaviour in rats. Psychopharmacology 1979, 66, 93-98. [CrossRef]

102. Silverman, A.P. Behaviour of rats given a 'smoking dose' of nicotine. Anim. Behav. 1971, 19, 67-74. [CrossRef]

103. Waldbillig, R.J. Suppressive effects of intraperitoneal and intraventricular injections of nicotine on muricide and shock-induced attack on conspecifics. Pharmacol. Biochem. Behav. 1980, 12, 619-623. [CrossRef]

104. Coura, R.S.; Cressant, A.; Xia, J.; de Chaumont, F.; Olivo-Marin, J.C.; Pelloux, Y.; Dalley, J.W.; Granon, S. Nonaggressive and adapted social cognition is controlled by the interplay between noradrenergic and nicotinic receptor mechanisms in the prefrontal cortex. FASEB J. 2013, 27, 4343-4354. [CrossRef] [PubMed]

105. Abrous, D.N.; Adriani, W.; Montaron, M.F.; Aurousseau, C.; Rougon, G.; Le Moal, M.; Piazza, P.V. Nicotine self-administration impairs hippocampal plasticity. J. Neurosci. 2002, 22, 3656-3662. [CrossRef]

106. Park, S.; Knopick, C.; McGurk, S.; Meltzer, H.Y. Nicotine impairs spatial working memory while leaving spatial attention intact. Neuropsychopharmacology 2000, 22, 200-209. [CrossRef]

107. Haam, J.; Yakel, J.L. Cholinergic modulation of the hippocampal region and memory function. J. Neurochem. 2017, 142, 111-121. [CrossRef]

108. Dineley, K.T.; Pandya, A.A.; Yakel, J.L. Nicotinic ACh receptors as therapeutic targets in CNS disorders. Trends Pharmacol. Sci. 2015, 36, 96-108. [CrossRef]

109. Bannerman, D.M. Fractionating spatial memory with glutamate receptor subunit-knockout mice. Biochem. Soc. Trans. 2009, 37, 1323-1327. [CrossRef] 
110. Cheng, Q.; Yakel, J.L. The effect of $\alpha 7$ nicotinic receptor activation on glutamatergic transmission in the hippocampus. Biochem. Pharmacol. 2015, 97, 439-444. [CrossRef]

111. Hsiao, C.J.; Lin, C.L.; Lin, T.Y.; Wang, S.E.; Wu, C.H. Imidacloprid toxicity impairs spatial memory of echolocation bats through neural apoptosis in hippocampal CA1 and medial entorhinal cortex areas. Neuroreport 2016, 27, 462-468. [CrossRef] [PubMed]

112. Zheng, M.; Qin, Q.; Zhou, W.; Liu, Q.; Zeng, S.; Xiao, H.; Bai, Q.; Gao, J. Metabolic disturbance in hippocampus and liver of mice: A primary response to imidacloprid exposure. Sci. Rep. 2020, 10, 5713. [CrossRef]

113. Jonas, P.; Lisman, J. Structure, function, and plasticity of hippocampal dentate gyrus microcircuits. Front. Neural Circuits 2014, 8 , 107. [CrossRef]

114. Hainmueller, T.; Bartos, M. Dentate gyrus circuits for encoding, retrieval and discrimination of episodic memories. Nat. Rev. Neurosci. 2020, 21, 153-168. [CrossRef] [PubMed]

115. Hampel, H.; Mesulam, M.M.; Cuello, A.C.; Farlow, M.R.; Giacobini, E.; Grossberg, G.T.; Khachaturian, A.S.; Vergallo, A.; Cavedo, E.; Snyder, P.J.; et al. The cholinergic system in the pathophysiology and treatment of Alzheimer's disease. Brain 2018, 141, 1917-1933. [CrossRef]

116. Maurer, S.V.; Williams, C.L. The cholinergic system modulates memory and hippocampal plasticity via its interactions with non-neuronal cells. Front. Immunol. 2017, 8, 1489. [CrossRef]

117. Vohra, P.; Khera, K.S.; Sangha, G.K. Physiological, biochemical and histological alterations induced by administration of imidacloprid in female albino rats. Pestic. Biochem. Physiol. 2014, 110, 50-56. [CrossRef] [PubMed]

118. Houchat, J.N.; Cartereau, A.; Le Mauff, A.; Taillebois, E.; Thany, S.H. An overview on the effect of neonicotinoid insecticides on mammalian cholinergic functions through the activation of neuronal nicotinic acetylcholine receptors. Int. J. Environ. Res. Public Health 2020, 17, 3222. [CrossRef] [PubMed]

119. Park, J.; Taly, A.; Bourreau, J.; De Nardi, F.; Legendre, C.; Henrion, D.; Guérineau, N.C.; Legros, C.; Mattei, C.; Tricoire-Leignel, H. Partial Agonist Activity of Neonicotinoids on Rat Nicotinic Receptors: Consequences over Epinephrine Secretion and In Vivo Blood Pressure. Int. J. Mol. Sci. 2021, 22, 5106. [CrossRef]

120. Kimura-Kuroda, J.; Komuta, Y.; Kuroda, Y.; Hayashi, M.; Kawano, H. Nicotine-like effects of the neonicotinoid insecticides acetamiprid and imidacloprid on cerebellar neurons from neonatal rats. PLoS ONE 2012, 7, e32432. [CrossRef] [PubMed]

121. Brini, M.; Calì, T.; Ottolini, D.; Carafoli, E. Neuronal calcium signaling: Function and dysfunction. Cell. Mol. Life Sci. 2014, 71, 2787-2814. [CrossRef] [PubMed]

122. Grienberger, C.; Konnerth, A. Imaging calcium in neurons. Neuron 2012, 73, 862-885. [CrossRef]

123. Simons, T.J. Calcium and neuronal function. Neurosurg. Rev. 1988, 11, 119-129. [CrossRef] [PubMed]

124. Aoyagi, M.; Arvai, A.S.; Tainer, J.A.; Getzoff, E.D. Structural basis for endothelial nitric oxide synthase binding to calmodulin. EMBO J. 2003, 22, 766-775. [CrossRef] [PubMed]

125. Griffith, O.W.; Stuehr, D.J. Nitric oxide synthases: Properties and catalytic mechanism. Annu. Rev. Physiol. 1995, 57, 707-734. [CrossRef] [PubMed]

126. Marletta, M.A. Nitric oxide synthase: Aspects concerning structure and catalysis. Cell 1994, 78, 927-930. [CrossRef]

127. McMurry, J.L.; Chrestensen, C.A.; Scott, I.M.; Lee, E.W.; Rahn, A.M.; Johansen, A.M.; Forsberg, B.J.; Harris, K.D.; Salerno, J.C. Rate, affinity and calcium dependence of nitric oxide synthase isoform binding to the primary physiological regulator calmodulin. FEBS J. 2011, 278, 4943-4954. [CrossRef]

128. Duzguner, V.; Erdogan, S. Chronic exposure to imidacloprid induces inflammation and oxidative stress in the liver \& central nervous system of rats. Pestic. Biochem. Physiol. 2012, 104, 58-64. [CrossRef]

129. Gaimarri, A.; Moretti, M.; Riganti, L.; Zanardi, A.; Clementi, F.; Gotti, C. Regulation of neuronal nicotinic receptor traffic and expression. Brain Res. Rev. 2007, 55, 134-143. [CrossRef]

130. Perry, D.C.; Dávila-García, M.I.; Stockmeier, C.A.; Kellar, K.J. Increased nicotinic receptors in brains from smokers: Membrane binding and autoradiography studies. J. Pharmacol. Exp. Ther. 1999, 289, 1545-1552.

131. Alcaro, A.; Huber, R.; Panksepp, J. Behavioral functions of the mesolimbic dopaminergic system: An affective neuroethological perspective. Brain Res. Rev. 2007, 56, 283-321. [CrossRef] [PubMed]

132. Bissonette, G.B.; Roesch, M.R. Development and function of the midbrain dopamine system: What we know and what we need to. Genes Brain Behav. 2016, 15, 62-73. [CrossRef] [PubMed]

133. Juárez Olguín, H.; Calderon Guzman, D.; Hernandez Garcia, E.; Barragan Mejia, G. The role of dopamine and its dysfunction as a consequence of oxidative stress. Oxid. Med. Cell. Longev. 2016, 2016, 9730467. [CrossRef]

134. Faro, L.R.F.; Oliveira, I.M.; Durán, R.; Alfonso, M. In vivo neurochemical characterization of clothianidin induced striatal dopamine release. Toxicology 2012, 302, 197-202. [CrossRef] [PubMed]

135. Faro, L.R.F.; Tak-Kim, H.; Alfonso, M.; Durán, R. Clothianidin, a neonicotinoid insecticide, activates $\alpha 4 \beta 2, \alpha 7$ and muscarinic receptors to induce in vivo dopamine release from rat striatum. Toxicology 2019, 426, 152285. [CrossRef]

136. Kawahata, I.; Yamakuni, T. Imidacloprid, a neonicotinoid insecticide, facilitates tyrosine hydroxylase transcription and phenylethanolamine N-methyltransferase mRNA expression to enhance catecholamine synthesis and its nicotine-evoked elevation in PC12D cells. Toxicology 2018, 394, 84-92. [CrossRef] [PubMed]

137. Daubner, S.C.; Le, T.; Wang, S. Tyrosine hydroxylase and regulation of dopamine synthesis. Arch. Biochem. Biophys. 2011, 508, 1-12. [CrossRef]

138. Danbolt, N.C. Glutamate uptake. Prog. Neurobiol. 2001, 65, 1-105. [CrossRef] 
139. Li, C.T.; Yang, K.C.; Lin, W.C. Glutamatergic dysfunction and glutamatergic compounds for major psychiatric disorders: Evidence from clinical neuroimaging studies. Front. Psychiatry 2019, 9, 767. [CrossRef]

140. Lewerenz, J.; Maher, P. Chronic glutamate toxicity in neurodegenerative diseases-What is the evidence? Front. Neurosci. 2015, 9 , 469. [CrossRef]

141. Ohgi, Y.; Futamura, T.; Hashimoto, K. Glutamate signaling in synaptogenesis and NMDA receptors as potential therapeutic targets for psychiatric disorders. Curr. Mol. Med. 2015, 15, 206-221. [CrossRef]

142. Reiner, A.; Levitz, J. Glutamatergic signaling in the central nervous system: Ionotropic and metabotropic receptors in concert. Neuron 2018, 98, 1080-1098. [CrossRef] [PubMed]

143. Mann, J.J. Role of the serotonergic system in the pathogenesis of major depression and suicidal behavior. Neuropsychopharmacology 1999, 21, 99-105. [CrossRef]

144. Štrac, D.Š.; Pivac, N.; Mück-Šeler, D. The serotonergic system and cognitive function. Transl. Neurosci. 2016, 7, 35-49. [CrossRef]

145. Calvo-Flores Guzmán, B.; Vinnakota, C.; Govindpani, K.; Waldvogel, H.J.; Faull, R.L.; Kwakowsky, A. The GABAergic system as a therapeutic target for Alzheimer's disease. J. Neurochem. 2018, 146, 649-669. [CrossRef] [PubMed]

146. Kilb, W. Development of the GABAergic system from birth to adolescence. Neuroscientist 2012, 18, 613-630. [CrossRef]

147. Meltzer, H. Serotonergic dysfunction in depression. Br. J. Psychiatry Suppl. 1989, 155, 25-31. [CrossRef]

148. Wassef, A.; Baker, J.; Kochan, L.D. GABA and schizophrenia: A review of basic science and clinical studies. J. Clin. Psychopharmacol. 2003, 23, 601-640. [CrossRef]

149. Abdollahi, M.; Ranjbar, A.; Shadnia, S.; Nikfar, S.; Rezaiee, A. Pesticides and oxidative stress: A review. Med. Sci. Monit. 2004, 10, RA141-RA147.

150. Agrawal, A.; Sharma, B. Pesticides induced oxidative stress in mammalian systems. Int. J. Biol. Med. Res. 2010, 1, 90-104.

151. Hayashi, M. Oxidative stress in developmental brain disorders. Neuropathology 2009, 29, 1-8. [CrossRef] [PubMed]

152. Gilgun-Sherki, Y.; Melamed, E.; Offen, D. Oxidative stress induced-neurodegenerative diseases: The need for antioxidants that penetrate the blood brain barrier. Neuropharmacology 2001, 40, 959-975. [CrossRef]

153. Gandhi, S.; Abramov, A.Y. Mechanism of oxidative stress in neurodegeneration. Oxid. Med. Cell. Longev. 2012, $2012,428010$. [CrossRef] [PubMed]

154. Salim, S. Oxidative stress and the central nervous system. J. Pharmacol. Exp. Ther. 2017, 360, 201-205. [CrossRef] [PubMed]

155. Annabi, E.; Ben Salem, I.; Abid-Essefi, S. Acetamiprid, a neonicotinoid insecticide, induced cytotoxicity and genotoxicity in PC12 cells. Toxicol. Mech. Methods 2019, 29, 580-586. [CrossRef]

156. Gasmi, S.; Kebieche, M.; Rouabhi, R.; Touahria, C.; Lahouel, A.; Lakroun, Z.; Henine, S.; Soulimani, R. Alteration of membrane integrity and respiratory function of brain mitochondria in the rats chronically exposed to a low dose of acetamiprid. Environ. Sci. Pollut. Res. Int. 2017, 24, 22258-22264. [CrossRef] [PubMed]

157. Lee, K.H.; Cha, M.; Lee, B.H. Neuroprotective Effect of Antioxidants in the Brain. Int. J. Mol. Sci. 2020, 21, 7152. [CrossRef]

158. Pisoschi, A.M.; Pop, A. The role of antioxidants in the chemistry of oxidative stress: A review. Eur. J. Med. Chem. 2015, 97, 55-74. [CrossRef]

159. Halliwell, B. Free radicals and antioxidants-quo vadis? Trends Pharmacol. Sci. 2011, 32, 125-130. [CrossRef] [PubMed]

160. Poljsak, B.; Šuput, D.; Milisav, I. Achieving the balance between ROS and antioxidants: When to use the synthetic antioxidants. Oxid. Med. Cell. Longev. 2013, 2013, 956792. [CrossRef]

161. Khan, J.Y.; Black, S.M. Developmental changes in murine brain antioxidant enzymes. Pediatr. Res. 2003, 54, 77-82. [CrossRef]

162. Dwivedi, D.; Megha, K.; Mishra, R.; Mandal, P.K. Glutathione in brain: Overview of Its conformations, functions, biochemical characteristics, quantitation and potential therapeutic role in brain disorders. Neurochem. Res. 2020, 45, 1461-1480. [CrossRef]

163. Nihei, H.; Kanemitsu, H.; Tamura, A.; Oka, H.; Sano, K. Cerebral uric acid, xanthine, and hypoxanthine after ischemia: The effect of allopurinol. Neurosurgery 1989, 25, 613-617. [CrossRef]

164. Kaminsky, Y.; Kosenko, E. Brain purine metabolism and xanthine dehydrogenase/oxidase conversion in hyperammonemia are under control of NMDA receptors and nitric oxide. Brain Res. 2009, 1294, 193-201. [CrossRef] [PubMed]

165. Kökoglu, E.; Belce, A.; Özyurt, E.; Tepeler, Z. Xanthine oxidase levels in human brain tumors. Cancer Lett. 1990, 50, $179-181$. [CrossRef]

166. Veljković, A.; Hadži-Dokić, J.; Sokolović, D.; Bašić, D.; Veličković-Janković, L.; Stojanović, M.; Popović, D.; Kocić, G. Xanthine Oxidase/Dehydrogenase Activity as a Source of Oxidative Stress in Prostate Cancer Tissue. Diagnostics 2020, 10, 668. [CrossRef]

167. Ott, M.; Gogvadze, V.; Orrenius, S.; Zhivotovsky, B. Mitochondria, oxidative stress and cell death. Apoptosis 2007, 12, 913-922 [CrossRef] [PubMed]

168. Guo, C.; Sun, L.; Chen, X.; Zhang, D. Oxidative stress, mitochondrial damage and neurodegenerative diseases. Neural Regen. Res. 2013, 8, 2003-2014. [CrossRef] [PubMed]

169. Nicolson, G.L. Mitochondrial dysfunction and chronic disease: Treatment with natural supplements. Integr. Med. (Encinitas) 2014, 13, 35-43. [PubMed]

170. Lakroun, Z.; Kebieche, M.; Lahouel, A.; Zama, D.; Desor, F.; Soulimani, R. Oxidative stress and brain mitochondria swelling induced by endosulfan and protective role of quercetin in rat. Environ. Sci. Pollut. Res. Int. 2015, 22, 7776-7781. [CrossRef]

171. Aquilano, K.; Baldelli, S.; Rotilio, G.; Ciriolo, M.R. Role of nitric oxide synthases in Parkinson's disease: A review on the antioxidant and anti-inflammatory activity of polyphenols. Neurochem. Res. 2008, 33, 2416-2426. [CrossRef] 
172. DiSabato, D.J.; Quan, N.; Godbout, J.P. Neuroinflammation: The devil is in the details. J. Neurochem. 2016, 139, 136-153. [CrossRef] [PubMed]

173. Norden, D.M.; Trojanowski, P.J.; Villanueva, E.; Navarro, E.; Godbout, J.P. Sequential activation of microglia and astrocyte cytokine expression precedes increased iba-1 or GFAP immunoreactivity following systemic immune challenge. Glia 2016, 64, 300-316. [CrossRef] [PubMed]

174. Ayoub, A.E.; Salm, A.K. Increased morphological diversity of microglia in the activated hypothalamic supraoptic nucleus. J. Neurosci. 2003, 23, 7759-7766. [CrossRef]

175. Stratoulias, V.; Venero, J.L.; Tremblay, M.È.; Joseph, B. Microglial subtypes: Diversity within the microglial community. EMBO J. 2019, 38, e101997. [CrossRef] [PubMed]

176. Zhou, B.; Zuo, Y.X.; Jiang, R.T. Astrocyte morphology: Diversity, plasticity, and role in neurological diseases. CNS Neurosci. Ther. 2019, 25, 665-673. [CrossRef] [PubMed]

177. Blandini, F. Neural and immune mechanisms in the pathogenesis of Parkinson's disease. J. Neuroimmune Pharmacol. 2013, 8, 189-201. [CrossRef]

178. Kigerl, K.A.; Gensel, J.C.; Ankeny, D.P.; Alexander, J.K.; Donnelly, D.J.; Popovich, P.G. Identification of two distinct macrophage subsets with divergent effects causing either neurotoxicity or regeneration in the injured mouse spinal cord. J. Neurosci. 2009, 29, 13435-13444. [CrossRef] [PubMed]

179. Akhmetzyanova, E.; Kletenkov, K.; Mukhamedshina, Y.; Rizvanov, A. Different approaches to modulation of microglia phenotypes after spinal cord injury. Front. Syst. Neurosci. 2019, 13, 37. [CrossRef]

180. Franco, R.; Fernandez-Suarez, D. Alternatively activated microglia and macrophages in the central nervous system. Prog. Neurobiol. 2015, 131, 65-86. [CrossRef]

181. Sonar, S.A.; Lal, G. The iNOS activity during an immune response controls the CNS pathology in experimental autoimmune encephalomyelitis. Front. Immunol. 2019, 10, 710. [CrossRef]

182. Ghasemi, M.; Fatemi, A. Pathologic role of glial nitric oxide in adult and pediatric neuroinflammatory diseases. Neurosci. Biobehav. Rev. 2014, 45, 168-182. [CrossRef]

183. Jaramillo, M.; Gowda, D.C.; Radzioch, D.; Olivier, M. Hemozoin increases IFN- $\gamma$-inducible macrophage nitric oxide generation through extracellular signal-regulated kinase-and NF-kB-dependent pathways. J. Immunol. 2003, 171, 4243-4253. [CrossRef] [PubMed]

184. Sheng, W.; Zong, Y.; Mohammad, A.; Ajit, D.; Cui, J.; Han, D.; Hamilton, J.L.; Simonyi, A.; Sun, A.Y.; Gu, Z.; et al. Proinflammatory cytokines and lipopolysaccharide induce changes in cell morphology, and upregulation of ERK1/2, iNOS and sPLA 2-IIA expression in astrocytes and microglia. J. Neuroinflamm. 2011, 8, 121. [CrossRef]

185. Choi, J.Y.; Nam, S.A.; Jin, D.C.; Kim, J.; Cha, J.H. Expression and cellular localization of inducible nitric oxide synthase in lipopolysaccharide-treated rat kidneys. J. Histochem. Cytochem. 2012, 60, 301-315. [CrossRef] [PubMed]

186. Jha, M.K.; Morrison, B.M. Glia-neuron energy metabolism in health and diseases: New insights into the role of nervous system metabolic transporters. Exp. Neurol. 2018, 309, 23-31. [CrossRef] [PubMed]

187. Camandola, S.; Mattson, M.P. Brain metabolism in health, aging, and neurodegeneration. EMBO J. 2017, 36, 1474-1492. [CrossRef] [PubMed]

188. Watts, M.E.; Pocock, R.; Claudianos, C. Brain energy and oxygen metabolism: Emerging role in normal function and disease. Front. Mol. Neurosci. 2018, 11, 216. [CrossRef] [PubMed]

189. Fotopoulou, E.; Lykogianni, M.; Papadimitriou, E.; Mavrikou, S.; Machera, K.; Kintzios, S.; Thomaidou, D.; Aliferis, K.A. Mining the effect of the neonicotinoids imidacloprid and clothianidin on the chemical homeostasis and energy equilibrium of primary mouse neural stem/progenitor cells using metabolomics. Pestic. Biochem. Physiol. 2020, 168, 104617. [CrossRef] [PubMed]

190. Bélanger, M.; Allaman, I.; Magistretti, P.J. Brain energy metabolism: Focus on astrocyte-neuron metabolic cooperation. Cell Metab. 2011, 14, 724-738. [CrossRef]

191. Kempermann, G.; Song, H.; Gage, F.H. Neurogenesis in the adult hippocampus. Cold Spring Harb. Perspect. Biol. 2015 , 7, a018812. [CrossRef]

192. Toda, T.; Parylak, S.L.; Linker, S.B.; Gage, F.H. The role of adult hippocampal neurogenesis in brain health and disease. Mol. Psychiatry 2019, 24, 67-87. [CrossRef] [PubMed]

193. Baptista, P.; Andrade, J.P. Adult hippocampal neurogenesis: Regulation and possible functional and clinical correlates. Front. Neuroanat. 2018, 12, 44. [CrossRef] [PubMed]

194. Mu, Y.; Gage, F.H. Adult hippocampal neurogenesis and its role in Alzheimer's disease. Mol. Neurodegener. 2011, 6, 85. [CrossRef] [PubMed]

195. Becerra, L.V.; Pimienta, H.J. Apoptosis neuronal: La diversidad de señales y de tipos celulares. Colomb. Med. 2009, 40, 124-133.

196. Fricker, M.; Tolkovsky, A.M.; Borutaite, V.; Coleman, M.; Brown, G.C. Neuronal cell death. Physiol. Rev. 2018, 98, 813-880. [CrossRef] [PubMed]

197. Méndez-Armenta, M.; Nava-Ruíz, C.; Juárez-Rebollar, D.; Rodríguez-Martínez, E.; Yescas Gómez, P. Oxidative stress associated with neuronal apoptosis in experimental models of epilepsy. Oxid. Med. Cell. Longev. 2014, 2014, 293689. [CrossRef]

198. Hollville, E.; Romero, S.E.; Deshmukh, M. Apoptotic cell death regulation in neurons. FEBS J. 2019, 286, 3276-3298. [CrossRef]

199. Blanquie, O.; Yang, J.W.; Kilb, W.; Sharopov, S.; Sinning, A.; Luhmann, H.J. Electrical activity controls area-specific expression of neuronal apoptosis in the mouse developing cerebral cortex. eLife 2017, 6, e27696. [CrossRef] 
200. Hirano, T.; Minagawa, S.; Furusawa, Y.; Yunoki, T.; Ikenaka, Y.; Yokoyama, T.; Hoshi, N.; Tabuchi, Y. Growth and neurite stimulating effects of the neonicotinoid pesticide clothianidin on human neuroblastoma SH-SY5Y cells. Toxicol. Appl. Pharmacol. 2019, 383, 114777. [CrossRef]

201. Chuderland, D.; Seger, R. Calcium regulates ERK signaling by modulating its protein-protein interactions. Commun. Integr. Biol. 2008, 1, 4-5. [CrossRef]

202. Cheng, P.; Alberts, I.; Li, X. The role of ERK1/2 in the regulation of proliferation and differentiation of astrocytes in developing brain. Int. J. Dev. Neurosci. 2013, 31, 783-789. [CrossRef] [PubMed]

203. Tomizawa, M.; Casida, J.E. Desnitro-imidacloprid activates the extracellular signal-regulated kinase cascade via the nicotinic receptor and intracellular calcium mobilization in N1E-115 cells. Toxicol. Appl. Pharmacol. 2002, 184, 180-186. [CrossRef]

204. Cheng, L.; Lu, Y.; Zhao, Z.; Hoogenboom, R.L.; Zhang, Q.; Liu, X.; Song, W.; Guan, S.; Song, W.; Rao, Q. Assessing the combined toxicity effects of three neonicotinoid pesticide mixtures on human neuroblastoma SK-N-SH and lepidopteran Sf-9 cells. Food Chem. Toxicol. 2020, 145, 111632. [CrossRef] [PubMed]

205. Şenyildiz, M.; Kilinc, A.; Ozden, S. Investigation of the genotoxic and cytotoxic effects of widely used neonicotinoid insecticides in HepG2 and SH-SY5Y cells. Toxicol. Ind. Health 2018, 34, 375-383. [CrossRef]

206. Mucchietto, V.; Fasoli, F.; Pucci, S.; Moretti, M.; Benfante, R.; Maroli, A.; Di Lascio, S.; Bolchi, C.; Pallavicini, M.; Dowell, C.; et al. $\alpha 9$-and $\alpha 7$-containing receptors mediate the pro-proliferative effects of nicotine in the A549 adenocarcinoma cell line. Br. J. Pharmacol. 2018, 175, 1957-1972. [CrossRef] [PubMed]

207. Wong, H.P.S.; Yu, L.; Lam, E.K.Y.; Tai, E.K.K.; Wu, W.K.K.; Cho, C.H. Nicotine promotes cell proliferation via $\alpha 7-$ nicotinic acetylcholine receptor and catecholamine-synthesizing enzymes-mediated pathway in human colon adenocarcinoma HT-29 cells. Toxicol. Appl. Pharmacol. 2007, 221, 261-267. [CrossRef]

208. Vinod, K.V.; Srikant, S.; Thiruvikramaprakash, G.; Dutta, T.K. A fatal case of thiacloprid poisoning. Am. J. Emerg. Med. 2015, 33, 310-e5. [CrossRef]

209. Marfo, J.T.; Fujioka, K.; Ikenaka, Y.; Nakayama, S.M.; Mizukawa, H.; Aoyama, Y.; Ishizuka, M.; Taira, K. Relationship between urinary N-desmethyl-acetamiprid and typical symptoms including neurological findings: A prevalence case-control study. PLoS ONE 2015, 10, e0142172. [CrossRef]

210. Agarwal, R.; Srinivas, R. Severe neuropsychiatric manifestations and rhabdomyolysis in a patient with imidacloprid poisoning. Am. J. Emerg. Med. 2007, 25, 844-845. [CrossRef]

211. Huang, N.C.; Lin, S.L.; Chou, C.H.; Hung, Y.M.; Chung, H.M.; Huang, S.T. Fatal ventricular fibrillation in a patient with acute imidacloprid poisoning. Am. J. Emerg. Med. 2006, 24, 883-885. [CrossRef]

212. Wu, I.W.; Lin, J.L.; Cheng, E.T. Acute poisoning with the neonicotinoid insecticide imidacloprid in N-methyl pyrrolidone. J. Toxicol. Clin. Toxicol. 2001, 39, 617-621. [CrossRef]

213. Gunier, R.B.; Bradman, A.; Harley, K.G.; Kogut, K.; Eskenazi, B. Prenatal residential proximity to agricultural pesticide use and IQ in 7-year-old children. Environ. Health Perspect. 2017, 125, 057002. [CrossRef]

214. Keil, A.P.; Daniels, J.L.; Hertz-Picciotto, I. Autism spectrum disorder, flea and tick medication, and adjustments for exposure misclassification: The CHARGE (CHildhood Autism Risks from Genetics and Environment) case-control study. Environ. Health 2014, 13, 3. [CrossRef]

215. National Research Council (US) Committee on Developmental Toxicology. Scientific Frontiers in Developmental Toxicology and Risk Assessment; National Academies Press: Washington, DC, USA, 2000.

216. Shelton, J.F.; Geraghty, E.M.; Tancredi, D.J.; Delwiche, L.D.; Schmidt, R.J.; Ritz, B.; Hansen, R.L.; Hertz-Picciotto, I. Neurodevelopmental disorders and prenatal residential proximity to agricultural pesticides: The CHARGE study. Environ. Health Perspect. 2014, 122, 1103-1109. [CrossRef]

217. Landrigan, P.J.; Goldman, L.R. Protecting children from pesticides and other toxic chemicals. J. Expo. Sci. Environ. Epidemiol. 2011, 21, 119-120. [CrossRef]

218. Pascale, A.; Laborde, A. Impact of pesticide exposure in childhood. Rev. Environ. Health 2020, 35, 221-227. [CrossRef] [PubMed]

219. Berheim, E.H.; Jenks, J.A.; Lundgren, J.G.; Michel, E.S.; Grove, D.; Jensen, W.F. Effects of neonicotinoid insecticides on physiology and reproductive characteristics of captive female and fawn white-tailed deer. Sci. Rep. 2019, 9, 4534. [CrossRef] [PubMed]

220. Wu, C.H.; Lin, C.L.; Wang, S.E.; Lu, C.W. Effects of imidacloprid, a neonicotinoid insecticide, on the echolocation system of insectivorous bats. Pestic. Biochem. Physiol. 2020, 163, 94-101. [CrossRef] [PubMed]

221. Fenton, M.B. Echolocation: Implications for ecology and evolution of bats. Q. Rev. Biol. 1984, 59, 33-53. [CrossRef]

222. Jakobsen, L.; Brinkløv, S.; Surlykke, A. Intensity and directionality of bat echolocation signals. Front. Physiol. 2013, 4, 89. [CrossRef] [PubMed]

223. Wenstrup, J.J.; Portfors, C.V. Neural processing of target distance by echolocating bats: Functional roles of the auditory midbrain. Neurosci. Biobehav. Rev. 2011, 35, 2073-2083. [CrossRef]

224. Wang, C.; Youle, R.J. The role of mitochondria in apoptosis. Annu. Rev. Genet. 2009, 43, 95-118. [CrossRef]

225. Korsmeyer, S.J.; Wei, M.C.; Saito, M.T.; Weiler, S.; Oh, K.J.; Schlesinger, P.H. Pro-apoptotic cascade activates BID, which oligomerizes BAK or BAX into pores that result in the release of cytochrome c. Cell Death Differ. 2000, 7, 1166-1173. [CrossRef] [PubMed]

226. Zhang, Q.; Liu, J.; Chen, S.; Liu, J.; Liu, L.; Liu, G.; Wang, F.; Jiang, W.; Zhang, C.; Wang, S.; et al. Caspase-12 is involved in stretch-induced apoptosis mediated endoplasmic reticulum stress. Apoptosis 2016, 21, 432-442. [CrossRef] 
227. Szegezdi, E.V.A.; Fitzgerald, U.N.A.; Samali, A. Caspase-12 and ER-stress-mediated apoptosis: The story so far. Ann. N. Y. Acad. Sci. 2003, 1010, 186-194. [CrossRef] [PubMed]

228. Ndebele, K.; Gona, P.; Jin, T.G.; Benhaga, N.; Chalah, A.; Degli-Esposti, M.; Khosravi-Far, R. Tumor necrosis factor (TNF)-related apoptosis-inducing ligand (TRAIL) induced mitochondrial pathway to apoptosis and caspase activation is potentiated by phospholipid scramblase-3. Apoptosis 2008, 13, 845-856. [CrossRef]

229. Hams, N.; Padmanarayana, M.; Qiu, W.; Johnson, C.P. Otoferlin is a multivalent calcium-sensitive scaffold linking SNAREs and calcium channels. Proc. Natl. Acad. Sci. USA 2017, 114, 8023-8028. [CrossRef] [PubMed]

230. Schug, N.; Braig, C.; Zimmermann, U.; Engel, J.; Winter, H.; Ruth, P.; Blin, N.; Pfister, M.; Kalbacher, H.; Knipper, M. Differential expression of otoferlin in brain, vestibular system, immature and mature cochlea of the rat. Eur. J. Neurosci. 2006, 24, 3372-3380. [CrossRef]

231. Shen, Y.Y.; Liang, L.; Li, G.S.; Murphy, R.W.; Zhang, Y.P. Parallel evolution of auditory genes for echolocation in bats and toothed whales. PLoS Genet. 2012, 8, e1002788. [CrossRef]

232. Dallos, P. Cochlear amplification, outer hair cells and prestin. Curr. Opin. Neurobiol. 2008, 18, 370-376. [CrossRef] [PubMed]

233. Morell, M.; Vogl, A.W.; IJsseldijk, L.L.; Piscitelli-Doshkov, M.; Tong, L.; Ostertag, S.; Ferreira, M.; Fraija-Fernandez, N.; Colegrove, K.M.; Puel, J.L.; et al. Echolocating whales and bats express the motor protein prestin in the inner ear: A potential marker for hearing loss. Front. Vet. Sci. 2020, 7, 429. [CrossRef] [PubMed]

234. Zheng, J.; Shen, W.; He, D.Z.; Long, K.B.; Madison, L.D.; Dallos, P. Prestin is the motor protein of cochlear outer hair cells. Nature 2000, 405, 149-155. [CrossRef]

235. Staes, N.; Sherwood, C.C.; Wright, K.; De Manuel, M.; Guevara, E.E.; Marques-Bonet, T.; Krützen, M.; Massiah, M.; Hopkins, W.D.; Ely, J.J.; et al. FOXP2 variation in great ape populations offers insight into the evolution of communication skills. Sci. Rep. 2017, 7, 16866. [CrossRef]

236. Li, G.; Wang, J.; Rossiter, S.J.; Jones, G.; Zhang, S. Accelerated FoxP2 evolution in echolocating bats. PLoS ONE 2007, 2, e900. [CrossRef]

237. Yin, J.X.; Ruan, Y.N.; Liu, J.L.; Zhang, S.Y.; Racey, P. FoxP2 expression in an echolocating bat (Rhinolophus ferrumequinum): Functional implications. Mamm. Biol. 2017, 85, 24-29. [CrossRef]

238. Zoli, M.; Pistillo, F.; Gotti, C. Diversity of native nicotinic receptor subtypes in mammalian brain. Neuropharmacology 2015, 96, 302-311. [CrossRef]

239. Zoli, M.; Pucci, S.; Vilella, A.; Gotti, C. Neuronal and extraneuronal nicotinic acetylcholine receptors. Curr. Neuropharmacol. 2018, 16, 338-349. [CrossRef]

240. Nair, L.R.; Liu, X. Targeting the $\alpha 4 \beta 2$-and $\alpha 7$-Subtypes of Nicotinic Acetylcholine Receptors for Smoking Cessation Medication Development. J. Addict. Res. Ther. 2019, 10, 381.

241. Wooltorton, J.R.; Pidoplichko, V.I.; Broide, R.S.; Dani, J.A. Differential desensitization and distribution of nicotinic acetylcholine receptor subtypes in midbrain dopamine areas. J. Neurosci. 2003, 23, 3176-3185. [CrossRef] [PubMed]

242. Zeid, D.; Kutlu, M.G.; Gould, T.J. Differential effects of nicotine exposure on the hippocampus across lifespan. Curr. Neuropharmacol. 2018, 16, 388-402. [CrossRef] [PubMed]

243. Wojda, U.; Salinska, E.; Kuznicki, J. Calcium ions in neuronal degeneration. IUBMB Life 2008, 60, 575-590. [CrossRef]

244. Bano, D.; Nicotera, P. Ca ${ }^{2+}$ signals and neuronal death in brain ischemia. Stroke 2007, 38, 674-676. [CrossRef]

245. Giorgi, C.; Baldassari, F.; Bononi, A.; Bonora, M.; De Marchi, E.; Marchi, S.; Missiroli, S.; Patergnani, S.; Rimessi, A.; Suski, J.M.; et al. Mitochondrial $\mathrm{Ca}^{2+}$ and apoptosis. Cell Calcium 2012, 52, 36-43. [CrossRef] [PubMed]

246. Morrissey, C.A.; Mineau, P.; Devries, J.H.; Sanchez-Bayo, F.; Liess, M.; Cavallaro, M.C.; Liber, K. Neonicotinoid contamination of global surface waters and associated risk to aquatic invertebrates: A review. Environ. Int. 2015, 74, 291-303. [CrossRef] [PubMed]

247. Sánchez-Bayo, F.; Goka, K.; Hayasaka, D. Contamination of the aquatic environment with neonicotinoids and its implication for ecosystems. Front. Environ. Sci. 2016, 4, 71. [CrossRef]

248. Zhang, P.; Ren, C.; Sun, H.; Min, L. Sorption, desorption and degradation of neonicotinoids in four agricultural soils and their effects on soil microorganisms. Sci. Total Environ. 2018, 615, 59-69. [CrossRef]

249. Han, W.; Tian, Y.; Shen, X. Human exposure to neonicotinoid insecticides and the evaluation of their potential toxicity: An overview. Chemosphere 2018, 192, 59-65. [CrossRef] [PubMed]

250. Ichikawa, G.; Kuribayashi, R.; Ikenaka, Y.; Ichise, T.; Nakayama, S.M.; Ishizuka, M.; Taira, K.; Fujioka, K.; Sairenchi, T.; Kobashi, G.; et al. LC-ESI/MS/MS analysis of neonicotinoids in urine of very low birth weight infants at birth. PLoS ONE 2019, 14, e0219208. [CrossRef]

251. Kavvalakis, M.P.; Tzatzarakis, M.N.; Theodoropoulou, E.P.; Barbounis, E.G.; Tsakalof, A.K.; Tsatsakis, A.M. Development and application of LC-APCI-MS method for biomonitoring of animal and human exposure to imidacloprid. Chemosphere 2013, 93, 2612-2620. [CrossRef]

252. Ohno, S.; Ikenaka, Y.; Onaru, K.; Kubo, S.; Sakata, N.; Hirano, T.; Mantani, Y.; Yokoyama, T.; Takahashi, K.; Kato, K.; et al. Quantitative elucidation of maternal-to-fetal transfer of neonicotinoid pesticide clothianidin and its metabolites in mice. Toxicol. Lett. 2020, 322, 32-38. [CrossRef] 
253. Ikenaka, Y.; Miyabara, Y.; Ichise, T.; Nakayama, S.; Nimako, C.; Ishizuka, M.; Tohyama, C. Exposures of children to neonicotinoids in pine wilt disease control areas. Environ. Toxicol. Chem. 2019, 38, 71-79. [CrossRef] [PubMed]

254. Casida, J.E. Neonicotinoid metabolism: Compounds, substituents, pathways, enzymes, organisms, and relevance. J. Agric. Food Chem. 2011, 59, 2923-2931. [CrossRef] [PubMed]

255. Dwyer, J.B.; McQuown, S.C.; Leslie, F.M. The dynamic effects of nicotine on the developing brain. Pharmacol. Ther. 2009, 122, 125-139. [CrossRef] [PubMed] 